Çukurova Üniversitesi Eğitim Fakültesi Dergisi

Vol: 50 Numb: 2 Page: 1210-1240

https://dergipark.org.tr/tr/pub/cuefd

\title{
Analysis of the Physical Structure of School Gardens as Learning Environments ${ }^{*}$
}

\author{
Zerrin MERCAN (ORCID ID - 0000-0002-9263-4363) \\ Büşra BILIRR (ORCID ID - 0000-0002-6240-8218) \\ Nilüfer DARICA (ORCID ID - 0000-0002-5369-9690)
}

Bartın Üniversitesi, Eğitim Fakültesi, Bartın/Türkiye Hasan Kalyoncu Üniversitesi, Eğitim Fakültesi, Gaziantep/Türkiye Hasan Kalyoncu Üniversitesi, Eğitim Fakültesi, Gaziantep/Türkiye

\begin{tabular}{l}
\hline Article Info \\
\hline DOI: $10.14812 /$ cufej.938581 \\
\hline Article history: \\
Received 18.05 .21 \\
Revised $\quad 07.10 .21$ \\
Accepted $\quad 08.10 .21$ \\
\hline Keywords: \\
Schoolyard \\
Learning environment \\
Preschool \\
Early childhood \\
Outdoor
\end{tabular}

\begin{abstract}
This research, which aims to examine school gardens as a physical learning environment, has been conducted in a qualitative research design. The research includes the gardens of 27 preschool education institutions in Gaziantep province. The "Schoolyard learning areas checklist", "colored matrices" and photographs, developed by the researchers, were used as data collection tools in the study. In the analysis of the data, content analysis was performed as well as percentage and frequency calculations. In the content analysis, the themes of physical areas, creative spaces, social areas, sensory areas and silent areas were created. As a result of the research, it was seen that physical and social areas exist throughout the school gardens, but they need qualitative support. It has been observed that the silent areas are very limited and positioned within the vocal areas. In addition, it was observed that creative and sense areas did not find a place in school gardens.
\end{abstract}

\section{Okul Bahçelerinin Fiziksel Yapısının Öğrenme Ortamı Olarak İncelenmesi}

\section{Makale Bilgisi}

DOI: $10.14812 /$ cufej.938581

\section{Makale Geçmişi:}

Geliş $\quad 18.05 .21$

Düzeltme $\quad 07.10 .21$

Kabul 08.10.21

Anahtar Kelimeler:

Okul bahçeleri

Açık alanlar

Öğrenme ortamı

Okul öncesi

Erken çocukluk

\section{Öz}

Okul bahçelerinin fiziksel öğrenme ortamı olarak incelenmesi amacıyla yapılan bu araştırma, nitel araştırma deseninde yapılmıştır. Araştırma, Gaziantep ilinde yer alan 27 okul öncesi eğitim kurumunun bahçesini içermektedir. Araştırmada veri toplama aracı olarak araştırmacılar tarafından geliştirilen "Okul bahçeleri öğrenme alanları kontrol listesi" "renkli matrisler " ve fotoğraflar kullanılmıştır. Verilerin analizinde yüzdelik ve frekans hesaplamalarının yanı sıra içerik analizi yapıımışırı. İ̧erik analizinde fiziksel alanlar, yaratıcı alanlar, sosyal alanlar, duyu alanları ve sessiz alanlar temaları oluşturulmuştur. Araştırmanın sonucunda, fiziksel ve sosyal alanların okul bahçelerinin genelinde var olduğu ancak niteliksel açıdan desteklenmeye ihtiyaç duyduğu görülmüştür. Sessiz alanların oldukça sınırlı olduğu ve sesli alanlar ile iç içe konumlandırıldığı görülmüştür. Ayrıca yaratıcı alanların ve duyu alanlarının okul bahçelerinde yer bulmadığı da görülmüş̧ür.

\footnotetext{
* This research was presented as an oral presentation at the International Congress of Early Childhood Outdoor Project.

†zmercan@bartin.edu.tr

tbusra.bilir@hku.edu.tr

§nilufer.darica@hku.edu.tr
} 


\section{Introduction}

All environments involving interpersonal interactions, where learning and teaching take place are referred to as educational environments (Kıldan, 2007). According to Aktaş Arnas (2019), preschool education institutions are environments where children spend most of their time outside their homes. According to Tepebağ and Arnas (2017), school gardens play an important role in helping children acquire skills that support all areas of development, and in meeting their educational and gaming needs. Especially considering that preschool children are in a rapid developmental period in the emotional, physical, linguistic, cognitive and social areas due to their age, it is necessary to pay more attention to the quality of the physical structure and features of school gardens. School gardens, as accessible and widespread learning environments, are areas that offer rich stimulating learning opportunities and possibilities. According to Malone and Tranter (2003), school gardens have a rich potential for formal learning.

National Association for the Education of Young Children (NAEYC), underlines the need for outdoor spaces and emphasizes that it should be included in educational programs. It is stated that school gardens, which should be used every day as a part of the educational program, are learning domains at their core (Copple \& Bredekamp, 2009). It is stated in UNICEF's (2009) report on child-friendly schools that "school is an important personal and social environment in the lives of students."

This significance requires child-friendly schools to be free from physical dangers to every child, emotionally reassuring them and psychologically supporting their development (Başbay, 2012). According to Başbay (2012), "School's garden should be transformed from being narrow spaces into a rich environment where all kinds of sports, artistic and gardening activities can be done that will develop the child's study, achievement, research and creative skills." Kytta (2004) defines school gardens as areas that have an ideal child-friendly environment and allow children to freely take advantage of these opportunities.

Children who start to be interested in nature at a very early age have developmentally unique experiences in outdoor games. Children can learn a lot of skills necessary in adulthood (including problem solving, social competence and creative thinking skills) through outdoor games (Rivkin, 1995, 2000; Moore \& Wong, 1997). School gardens are the only open spaces that children can access easily and reliably (Aktaş Arnas, 2019). These areas, which are important for the development of children, are mostly used for parking, covered with asphalt or concrete, with a few trees and flowers to give the appearance of a garden, albeit a little. School gardens should be planned as outdoor playgrounds where children can be supported developmentally, rather than a haphazardly prepared place away from education. When these areas are shaped in the wrong direction in terms of planning, children get the feeling that their own needs are not valuable (Campbell, 2013).

According to Regulation on Pre-School Education Institutions, Article 54; in order for education to be carried out in a healthy and appropriate environment in preschool educational institutions, it is essential that there is a playground and a garden and to arrange them in accordance with their purpose. While making this arrangement; care is taken to ensure that there is a traffic training track, a sandbox, garden play tools, as well as enough land for children to do science and nature studies (MEB Mevzuat Bankası, 2004). MEB Regulations recommend that school gardens be arranged with an area of $3 \mathrm{~m}^{2}$ per child at the pre-school education level, and $10 \mathrm{~m}^{2}$ for each child at the primary/secondary education levels. Additionally, it is also recommended that there are grassy/pebble areas, areas for cycling, a sandbox, trees, earth mounds and, if possible, an open-air theatre, small houses, herb gardens, animal feeding areas, a pool, a warehouse and such supplements in the garden, also protecting the perimeter of the garden with wire, fence or wall (Poyraz \& Dere, 2003; MEB Mevzuat Bankası, 2004).

The school gardens meet the needs of children in the open space, while allowing children to move. Thus, they allow children to meet their daily movement needs, reduce their energy, reduce stress, and get rid of diseases such as asthma, obesity. According to Del Alamo (2005), the playgrounds located in 
the school gardens are quite important. These areas can be defined as physical, social, sensory, creative and silent playgrounds.

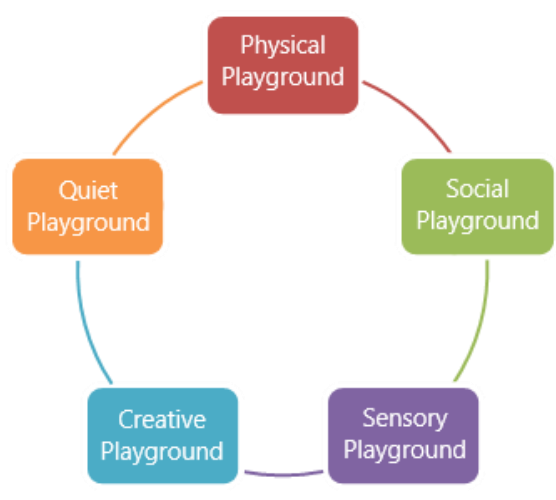

Image 1.

Del Alamo's (2005) classification of playgrounds located in school gardens

The most widely accepted value of outdoor activities for children is the benefit on the physical development of children. In their study, Grubbels and others (2012) concluded that children were more mobile in areas where there are jumping tools or where there are landmarks for running. To support children's physical development, lounging, holding, pushing, moving, balancing, climbing, pulling, digging, crawling, jumping, running, swinging, vaulting, leaping, gripping, swimming, falling, embarking and stretching are needed (Campbell, 2013; Frost at all 2004). Providing such opportunities to children allows them to learn how to safely activate their bodies by utilizing the resources around them (Aktaş Arnas, 2019).

One of the environments with an important potential to support children's social and emotional development areas is school gardens. Children spontaneously initiate communication and interaction with each other while playing, and they discuss, change and develop the rules among themselves. They learn cooperation and reconciliation as a result of the conflicts that arise in the games (Burdette and Whitaker, 2005). Playing is a very serious endeavor for the child and is also a source of development, learning and entertainment (Aral and others. 2001; Çoban and Nacar 2006; Melendez and others 2000). Participating in a game environment gives the child the opportunity to acquire skills that are important for his social development, such as understanding the roles of life, problem solving, thinking, interacting with the environment, helping, sharing and speaking (Durualp and Aral, 2010). Behaviors that are necessary for life in the game environment, especially social skills, are learned naturally (Darwish and others 2001; Swindells and Stagnitti 2006).

Scientifically ideal environments for the senses are; changing and changeable environments. The fact that the environment is a rich stimulating atmosphere, allows children to focus, concentrate and develop awareness (Day \& Midbjer, 2007). In addition, the fact that outdoor playing/learning areas offer aesthetic experiences is an important factor that will affect children's senses. It is necessary to use various materials such as sand, soil, water, natural materials, play dough, clay, soap and foams to support children in the classroom and out of the classroom (in school gardens) (Levne, 2006). Children use many of their different senses while they are in playgrounds (Sapsağlam, 2018). Through sensory games, children with limited skills in one or more sensory areas can use different sensory areas more effectively (Öncü, 2020). In this direction, it is possible for every child to increase their existing sensory capacities, to taste the sense of success, to explore the world and develop their knowledge infrastructure through sensory experiences (Snyder \& others. 2011).

Creativity is a process that involves associating with experiences and responding to stimuli (people, symbols, situations, ideas, objects). In terms of such stimuli, the natural environment is rich and complex. Creative areas can also be considered as areas that allow children to take risks, gradually 
accommodate difficulties and provide an opportunity to play different types of games (Aktaş Arnas, 2019). When school gardens are evaluated ecologically and pedagogically; they should consist of natural learning environments (Karakaya \& Kiper, 2013). In this context, various uses should be included to develop the creative aspects of children. Ground shapes and hillocks that increase gaming possibilities provide powerful and creative playgrounds (Casey, 2005).

Quiet playgrounds should include areas for hidden, private play areas and common use areas (Walsh, 2016). Structured play, one of the main points in the design of school gardens, should include creating new games, playing with natural elements such as water and sand, and various activity areas, including divided playgrounds for quiet games (Arnold, 1996). It is an important element that the said area is not under the sun and is protected with elements which provide shade (Del Alamo, 2005). According to Walden (2009), quiet playgrounds designed for children provide a good opportunity to carry out the prevention of crime or bullying, as it requires them to play in quiet areas and respect each other's private life.

When planning school gardens, it is necessary to have a high level of security, to use healthy tools and materials, and the principles of supporting development areas should be in place. When making plans, it should also be taken into account that the area has features that will produce accessible, sustainable, practical, meaningful and creative ideas (Aktaş Arnas, 2019).

Considering the importance of children's learning and development processes in open spaces, school gardens should be well designed (Arabacı \& Çıtak, 2017; Aslan, 2010; Basar, 2020; Cooper, 2015; Wake \& Birdsall, 2016). Based on all these needs, this study aims to examine school gardens in a physical context as a learning environment.

\section{Method}

\section{Model of the Research}

In this research, which was planned in a qualitative research design, the observation and document analysis technique was used. Model of the research is presented in image 2.

Image 2.

Model of the research

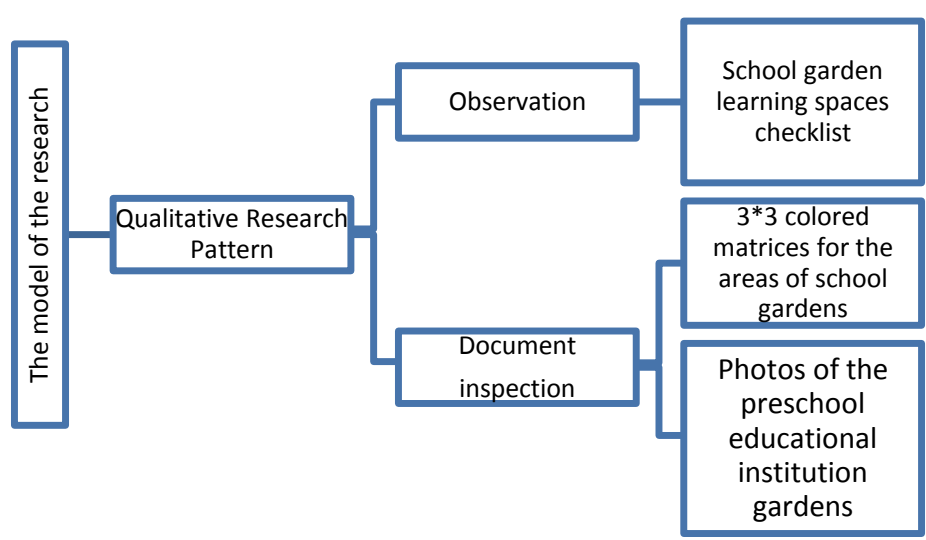

The "School garden learning areas checklist" prepared by the researchers was used for the purpose of observing school gardens. This list is a Likert type list consisting of demographic information for school gardens and questions about the stimulation of learning environments. The said list was used by two researchers, so that it was aimed to ensure consistency between observers and increase the reliability of the observation. In this checklist, school gardens were evaluated according to the Del Alamo (2005) classification (physical playgrounds, creative playgrounds, social playgrounds, sensory playgrounds and quiet areas). 
In the research, photographs and colored matrices were used in the document review technique. The photos show the school gardens of 27 preschool education institutions. The photographs were taken by the researchers at the time of observation, and care was taken to include many different areas such as physical playgrounds, creative playgrounds, social playgrounds, sensory playgrounds and quiet areas.

The colored matrices for the areas of the school gardens were developed by the researchers as $3 * 3$ matrices, and the "Location matrices of the school gardens" developed by Başbay (2012) were used in this context. "Color matrices for the areas of school gardens" were created by coding them with different colors for each learning area.

\section{Participants}

The working group of the study consists of 27 preschool educational institutions located in Şahinbey and Şehitkamil Districts of Gaziantep Province. Chart 1 shows the demographic information for schools.

\section{Chart 1.}

Demographic information about the schools included in the study

\begin{tabular}{ll|l}
\hline & Public & Private \\
\hline Şahinbey & 7 & 3 \\
Şehitkamil & 12 & 5
\end{tabular}

According to the type of institution, it can be said that $77.8 \%$ of the 27 preschool educational institutions consist of independent kindergartens affiliated to the Ministry of Education and $22.2 \%$ consist of private kindergartens.

\section{Used Data Collection Tools}

As a data collection tool in the research, in "The school gardens learning areas checklist" developed by the researchers, photos showcasing the areas in the $3^{*} 3$ school gardens with colored matrices and different learning areas in the school gardens (physical playground, social playground, creative playground, sensory playground, silent area) were used.

"The school gardens learning areas checklist" was created by researchers using the relevant field article. The school gardens learning areas checklist consists of 53 articles. The 53 articles in the checklist were revised considering Del Alamo's (2005) classification, and the 9 articles excluded from the reclassification were deemed appropriate to be removed from the checklist, and the form was finalized with 44 articles. The two-part checklist includes demographic information and articles related to the stimulation of learning environments. Each article was conceived as a Likert type rating tool consisting of 0-5 scoring system, and was rated between $0-5$ by the researchers. In this scoring, an evaluation was made from "the least" to "the most". In this context, it is aimed to evaluate according to the Del Alamo (2005) classification (physical playgrounds, creative playgrounds, social playgrounds, sensory playgrounds and quiet areas). For this purpose, the checklist was filled out separately by two researchers, and the consistency between the researchers was calculated and the reliability of the research data was increased.

The school garden learning areas checklist is shown in chart 2. 
Chart 2.

The school garden learning areas checklist

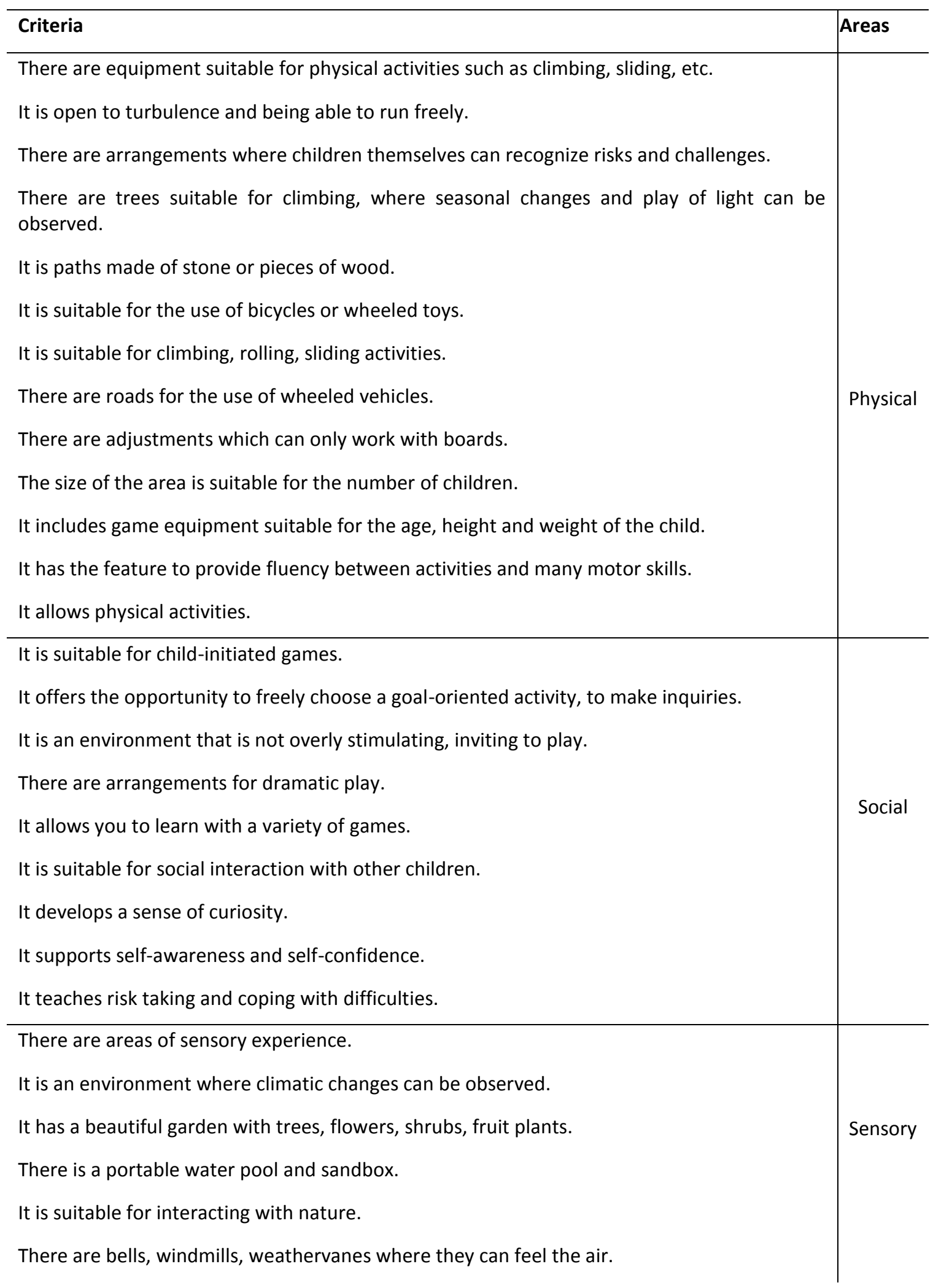


It is suitable for examining aquatic plants, fruits, plants with different odors.

There are materials that children can use with their hands and fingers.

There is a large sandbox.

It provides opportunities to understand how natural events can change the environment.

It gives a sense of aesthetics.

There are areas which contain different plants.

There are both natural and man-made materials of different textures.

There are areas suitable for innovation and diversity.

Art events can be held.

It allows for a wide variety of activities.

It provides rich sensory experiences that teach awareness of the body, space, time and direction.

It improves creativity.

There are rich stimuli which supports learning.

There are benches for resting.

It includes sunny and shaded areas.

There are areas for silence and rest.

Colored matrices were used in the evaluation of school gardens as a learning environment, and each color was associated with one or more items in these matrices. The colored matrices showing the areas in these $3 * 3$ school gardens were intended to visually identify the different areas located in the school gardens. Therefore, a specific color was coded for each area, such as green fields green, concrete areas gray, land areas brown and so on, and a 27-color matrix describing 27 school gardens was created by the researchers in line with these coding's. Care was taken to define the existing areas in the color coding. For example, land areas are coded as brown, concrete areas as gray, and green fields as green. In this context, the color codes used in colored matrices are shown in Image 3. 
Image 3.

Color codes used in matrices
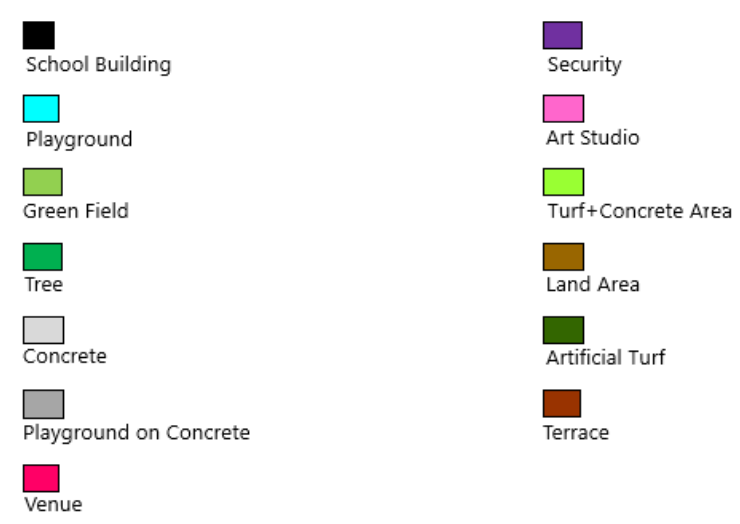

"Photographs showing different learning areas in school gardens" were taken by researchers for the purpose of observing school gardens. These photos show the gardens of 27 preschool educational institutions. It was preferred by researchers to support and concretize other documents.

\section{Data Analysis}

The data related to the "School gardens learning areas checklist" were analyzed with percentile and frequency distributions. Additionally, the "School garden learning areas checklist" was evaluated with content analysis with colorful matrices and photographs, themes were created in this context, and the findings related to the themes were discussed with the body of literature.

\section{Findings and Interpretation}

The findings of this research show that the percentage calculations for the "School gardens learning areas checklist" consists of color matrices for learning areas and themes and sub-themes related to the content analysis of photos.

\section{Findings Related to the Checklist}

The findings obtained from the "School gardens learning areas checklist" were handled in 5 main themes, taking into account the Alamo (2005) classification, and content analysis was carried out in line with these themes. The findings obtained from this analysis are as follows:

Chart 3.

Percentage Distribution of the Items in the Checklist by Area

\begin{tabular}{lccccccc}
\hline Areas & $\begin{array}{c}\text { The Number of Items on } \\
\text { the Checklist by Area }\end{array}$ & $\mathbf{0}$ none & $\begin{array}{c}\mathbf{1} \text { very } \\
\text { little }\end{array}$ & $\mathbf{2}$ little & $\begin{array}{c}\mathbf{3} \\
\text { modera } \\
\text { te }\end{array}$ & $\begin{array}{c}\mathbf{4} \\
\text { good }\end{array}$ & $\begin{array}{c}\mathbf{5} \text { very } \\
\text { good }\end{array}$ \\
\hline $\begin{array}{l}\text { Physical Area } \\
\text { Social Area }\end{array}$ & 13 & $32.7 \%$ & $18.8 \%$ & $16.2 \%$ & $14.2 \%$ & $10.5 \%$ & $8.5 \%$ \\
$\quad$ & 9 & $31.4 \%$ & $29.1 \%$ & $19.4 \%$ & $15.2 \%$ & $9.7 \%$ & $7.4 \%$ \\
$\quad \begin{array}{l}\text { Creative } \\
\text { Area }\end{array}$ & 6 & $25.9 \%$ & $27.6 \%$ & $25.9 \%$ & $13.5 \%$ & $7.4 \%$ & 0 \\
$\begin{array}{l}\text { Sensory Area } \\
\text { Quiet Area }\end{array}$ & 13 & $34.4 \%$ & $19.3 \%$ & $22.7 \%$ & $11.3 \%$ & $6.5 \%$ & $4.2 \%$ \\
\hline
\end{tabular}


According to Chart 3, it can be seen that the physical area is very good by $8.5 \%$, is good by $10.5 \%$, is little by $16.2 \%$, is very little by $18.8 \%$ and meets the criteria by $32.7 \%$, while $32.7 \%$ does not meet the criteria at all. The relevant field underlines how important physical areas are in meeting the movement needs of children, supporting their health and well-being. Participation in movement and physical activity is extremely important for the child's better growth and development, gaining an active lifestyle, reducing the risks of future diseases and preventing excessive weight gain (Çelik and Şahin, 2013). According to Karadağ, Mutlu and Sayın (2012), playing is one of the main components that allows the child to develop healthily in terms of body, mind, psychology and social aspects. According to Tandoğan (2016), activities such as running, climbing, jumping, walking on a wall, playing with water, sand, soil, which are the natural needs of a child, support the physical development of the child, allow him to learn his body and limits and become aware of his abilities. It has been observed that school gardens contain equipment suitable for physical activities (such as playgrounds, floor designs for group games), but these equipment are uniform and limited. For this reason, it is necessary to provide equipment that will support children's participation in different physical activities.

Kaçan, Halmatov and Kartaltepe (2017) state that school gardens are frequently used for playing, movement, science and field trip activities. However, it is emphasized in the relevant article that there should be school garden areas such as:

- Areas for Art, music and performance studies (camellia type),

- Areas for science education studies (plant cultivation, experiment, observation, watering),

- Small zoo (care and feeding of animals such as chickens, dogs and rabbits),

- Areas for learning traffic rules, children's exhibitions, sandbox, active and free

- Grass area for activities (running, playing ball, jumping, traditional children's games etc.),

- A study, experiment, observation and seating area for teachers and parents.

(Collyer and Irvine, 2001; Fisman, 2001; Pickard, 2002; Corson, 2003; Özdemir and Yılmaz, 2009; Aktaran: Kaçan, Halmatov and Kartaltepe, 2017, Başar, 2020)

All these areas provide opportunities for different and varied activities. However, the findings of the research show that school gardens contain limited diversity. School gardens can appeal to children with different interests, abilities and experiences by hosting different and varied activities.

School gardens should be arranged as social spaces that provide physical activity and playing opportunities to students (Özdemir and Yılmaz, 2009). Planning of playgrounds in schools allows students to perform various activities such as running, jumping, bouncing, throwing, swinging, climbing, catching, and physical activity levels improve as a result of movements (Vural and Yılmaz, 2016). In 1994, The 21st Century School Fund program was established for the formation of qualified schools in America that are safe, healthy and support education. According to the report published by this organization in 2011, children need activities to be carried out in the relevant field in order to support their physical development for at least one hour a day. In order to respond to the needs of children and support them, it is necessary to include physical activities related to the play and sports areas that should be located in the school gardens (21st CSF, 2011).

According to Ural (2007), "the richer and more interesting stimuli the environment offers, the more opportunities children will have to learn. In all educational institutions, the physical environment is effective on the behavior and development of the individual, especially in pre-school education institutions where the physical, mental and psychosocial development of the child is very fast and these development areas are shaped." In order for the instructor to be efficient and the program to be implemented as desired, the physical environment must be appropriate and the equipment must be sufficient. The environment should provide what the children need to learn (Aktaran, Başbay, 2012).

School gardens should be of a quality that can reliably, healthily and richly meet the children's needs for playing. The findings of the study show that school gardens meet the playing needs in a limited way. 
Playing, which is of great importance in the child's life, should be met at school, which has a very important place in the child's life, and school gardens should be used for this purpose, especially as the open spaces of schools. Therefore, the school gardens need to be reorganized to accommodate various games.

In Louv's (2005) book titled "The Last Child in Nature", they underline that children need to run and play freely and that nature is a very important requirement for this, and that these freedoms are limited or terminated by urbanization. However, the conducted research shows that the level of physical activity of school-age children has decreased, especially in the last two decades (Dyment, Bell \& Lucas, 2009; Cengiz and İnce, 2013). According to Aksu and Demirel (2011), decreasing open spaces due to urbanization limit children's playgrounds. The game environment that supports the holistic development of the child should be provided in school gardens. For this reason, it is important that the areas located in the school gardens are large and qualified to support children's physical and mental activity. School gardens, which are the most easily accessible outdoor learning environments for children, may be areas that can support the child in this context. However, the findings of the research show that school gardens are limited in this context.

According to Chart 3, it is seen that the social area met the criteria $7.4 \%$ very good, $9.7 \%$ good, $15.2 \%$ moderate, $19.4 \%$ little, $29.1 \%$ very little, and $31.4 \%$ did not meet the criteria at all. The relevant article underline how important social areas are for children to get to know themselves and others, to have self-confidence and self-expression, to adapt to community life and to socialize.

Başbay (2012) states that child-friendly schools allow the child to have confidence in himself and his environment. According to the findings of the research, only 8 out of 27 schools are capable of allowing the child to know themselves and to have self-confidence. 17 schools do not have the conditions to support this self-confidence. In this case, when organizing school gardens, it is extremely important that school gardens are considered as a social learning environment and are designed as environments where the child can recognize himself, act independently and freely do activities that he will have selfconfidence in.

School gardens are areas that develop social interaction, interaction with the natural environment, physical activity, creativity and problem solving skills (Wood and Martin, 2000). Social interaction, defined as the initiation and maintenance of communication between children and their peers, can be supported by the arrangement of school gardens as a social learning environment. According to the findings of the research, school gardens support social interaction at a certain level. That is why it is necessary to develop school gardens in such a way as to support social interaction, encourage the playing of group games.

The fact that the school gardens contain equipment suitable for the child provides the child with a comfortable and safe space (Uzut, 2020). Thus, the child is given positive messages in this area, and the child is in a learning environment where he can easily express himself and his trust.

According to Chart 3, it is seen that the creative area met the criteria of $7.4 \%$ very good, $13.5 \%$ good, $25.9 \%$ moderate, $27.6 \%$ little and $25.9 \%$ very little, meaning none of which met the criteria very well. The related article underlines how important creative areas are for children to express themselves in creative ways, show innovative skills and be open to innovations.

Preschool education program, "Development of Creativity is at the Forefront: Opportunities should be created for children to express themselves in different ways and in an authentic way in environments suitable for their learning needs and learning styles (MEB, 2013). For this purpose, the individual differences of children should be supported with different materials, different methods and techniques in the learning process."

Although $77.8 \%$ of the schools participating in the study were MEB-affiliated independent kindergartens and the MEB (2013) preschool education program prioritizes creativity, the findings of the 
research shows that the school gardens covered in the Gaziantep province does not support creativity. In this case, it is very important to have creative materials in school gardens, to create creative environments, and to use existing environments in creative ways.

The related article mentions the importance of taking "controlled risks" in children's creativity. According to Kalburan (2014), outdoor play provides very important opportunities for children to explore their surroundings, learn to avoid injury, realize the risks through learning what their bodies can do, evaluate them, and fight them. Bundy, Luckett, Tranter, Naughton, Wyver, Ragen and Spies (2009) state that children not taking any risks is a risk by itself, and emphasize the importance of children taking risks so that they can cope with them. Therefore, in the process of organizing and using school gardens, the need for children to take and experience the risks they can cope with in a safe environment should be realized and physical and social arrangements should be made to meet this need.

According to Nur (2019), children need to take risks and be challenged, provided that they are not in any danger. Thus, children can gain the ability to effectively manage risks and test their self-confidence. According to Alat, Akgümüş and Cavalı (2012), taking risks, coping with risky situations that make it easier to adapt to life in adulthood, being responsible for the consequences of their own decisions and behaviors, and learning the limits of their own skills and capacities allows them to acquire quite important skills that should be acquired at an early age. For this reason, it is important that school gardens provide opportunities for children to take "controlled risks" and "reasonable risks". The findings of the research show that school gardens need to be reorganized for risk taking.

According to Çukur and Delice (2011), the fact that school gardens contain materials with different textures supports children's creativity and provides opportunities for different types of playing. It also helps the child's perception development. In addition, spaces created with different and rich textures also feed children's visual perceptions, which include many areas such as color, form and perspective. For this reason, the presence of materials of different textures in school gardens should be supported. However, the findings of the research show that school gardens are limited in this context.

According to Chart 3 , it is seen that the sensory area met the criteria of $4.2 \%$ very good, $6.5 \%$ good, $11.3 \%$ moderate, $22.7 \%$ low, $19.3 \%$ very little, and $34.4 \%$ were inadequate. The relevant article emphasizes the importance of the senses in early childhood and emphasizes that sensory experiences can be supported in open spaces and school gardens.

Cooper (2005) states that the senses have an important place in the development of children. From the first year of their lives, children begin to perceive and recognize the world and their environment through their bodies. Having not yet clearly acquired the coordination of movements of their bodies or comprehended the acquisition of language with childbirth, they try to understand the environment in which they live with the help of their sensory organs. One of the most important of these senses is the sense of touch. Children develop other emotions by touching and moving. Like Montessori, Frobel, Piaget, Rousseau, the educators who laid the foundations of early childhood education, emphasized the importance of moving and developing the senses and emphasized that outdoor games support children's sensory development (Bilton, 2010). Outdoor games provide important opportunities for supporting children's senses. Uslu and Shakouri (2012) stated that children should be in environments that appeal to different senses that support their development, where there are plants with different odors, and materials in different structures and textures. According to Çelik (2012), gardens are areas that will allow students to gain sensory experiences with the elements of the world of living things in preschool educational institutions. According to Huz and Kalburan (2017), school gardens offer a learning environment that activates all the senses and is based on experimentation, discovery and research. The findings regarding the inclusion of sensory experience areas in school gardens indicate that school gardens are limited in this context. 
According to Chart 3 , it is seen that the quiet area met the criteria $8.6 \%$ very good, $12.3 \%$ good, $11.1 \%$ moderate, $20.9 \%$ little, $19.7 \%$ very little, and $27.1 \%$ met the insufficient criterion. The relevant article states that quiet areas allow children to rest and are necessary for the development of children.

Quiet, calm areas are as important as the areas that allow children to move, for them to rest, observe their surroundings, and explore playgrounds. The fact that children are left alone also supports their independence and making their own decisions. These areas provide important opportunities for teachers to observe the children as well. Instead of leaving these areas completely empty, enriching them with materials such as water and a sandbox, cushions makes the environment more attractive for children. Additionally, these areas need to be configured in a shaded area (Del Alamo, 2005). Petalozzi compares the classroom to the child's living room and the school's garden to their rest area (Gollwitzer et. al, 1959: 5; as cited in Başar, 2020). With this statement, Pestalozzi emphasizes that the exterior is as important as the interior space. When children spend quality time outdoors, they will make connections about the inner and outer world more easily, they will have a better sense of daily life, and they will achieve this through their senses. At this point, nurturing and supporting children's senses outdoors is an important element (Başbay, 2012). According to Vural and Yılmaz (2018), school gardens should be designed and arranged to meet different needs. Quiet areas are important because they provide an opportunity for children to relax and are one of the areas that should be located in the school gardens. However, the findings of the research reveal that school gardens are insufficient in this context.

\section{Findings on Colored Matrices}

School gardens were prepared as $3 * 3$ matrices, and at this stage, the processes of Başbay (2012) matrix formation were taken as basis. $3 \times 3$ generated position matrices developed by Başbay (2012) were used. It was aimed to determine the location of school gardens relative to school buildings, and in this matrix, it was aimed to determine the indoor (school building) and outdoor areas (garden, playground) in the school.

\section{Image 4.}

\section{Example Matrices}
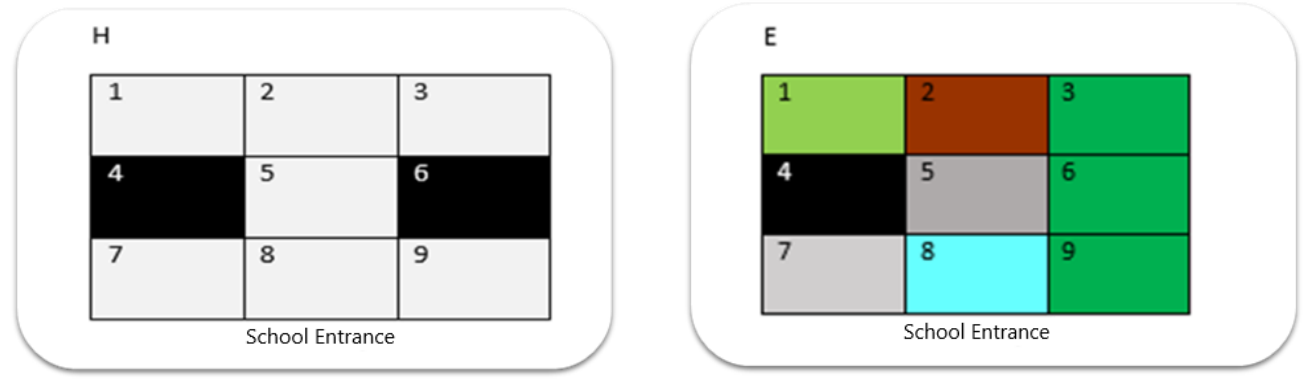

When colored matrices are examined in the evaluation of school gardens as a learning environment, it is seen that there are more physical areas and social areas located than creative areas, sensory areas and quiet areas.

It is seen that the size and location of physical areas vary according to schools, schools often have large school gardens in terms of quantity, and concrete areas are concentrated in these gardens. It has been observed that playgrounds structured in physical areas are located in the vast majority of schools, and playgrounds are often located in front of school gardens, and side and backyards are used in a limited number of schools.

It is seen that the social areas are designed for the use of group games, which are usually drawn on the concrete area. However, it can be said that green areas, land areas etc. devoted to social areas have limited space. In this context, matrices containing social areas often consist of gray tones. Although the 
location of the social areas in the school gardens vary, it can be said that they are often located in front of the school garden. This may have been done with the aim of making social spaces visible and controllable, safe environments.

When creative areas are examined, it is seen that schools generally do not include them, and very few schools include art areas or a rich stimulating environment which supports creativity. Creative areas are shown in pink color tones as they contain art areas, performance centers etc. in colored matrices. It has been observed that the limited number of creative areas available are located at the school entrance.

When the sensory areas are examined, it is seen that they're not located in the school gardens and they're in need of support. Since the sensory areas are not located in the school gardens, there has also been no findings related to its location. However, the land areas, green areas and concrete areas located in the school gardens can be converted into sensory areas.

When quiet areas are examined, it is seen that rest benches are used throughout the schools, but there are no suitable environments for children to stay in quiet areas and to meet their reading, resting and similar needs in this area. It has been observed that the existing quiet areas are often intertwined with loud areas such as playgrounds.

\section{Findings Related to the Photographs}

Photographs of school gardens were also used to evaluate school gardens as learning environments. The areas located in the school gardens (physical area, quiet area, sensory area, creative area and social area) were also supported by the analysis of these photographs.

When the photos are examined, it can be seen that concrete areas are frequently used as physical areas of school gardens, there are less green areas, and it is seen that swings, slides and such game tools are used to support the movement. Even though there are some schools that have playhouses, climbing areas etc., they are quite limited.

\section{Image 5.}

A sample photo of physical playgrounds and a photo of the examined school gardens
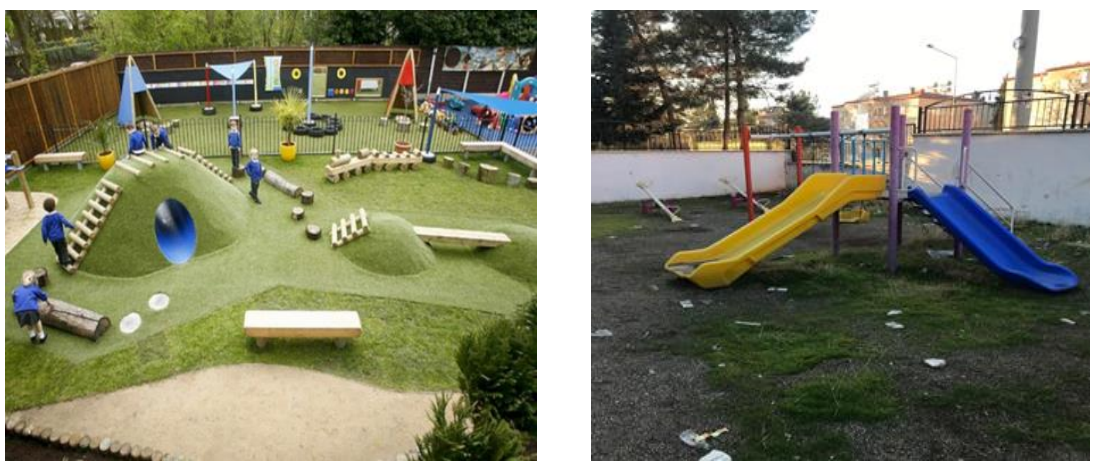

When the photos for the social areas are examined, it is seen that the areas for playing group games in the school gardens were created in the concrete area. But these areas are also not included in all schools. Nevertheless, the areas that support the social area like the drama area, playgrounds, and group areas for socializing were not observed. 
Image 6.

A sample photo of social playgrounds and a photo of the examined school gardens
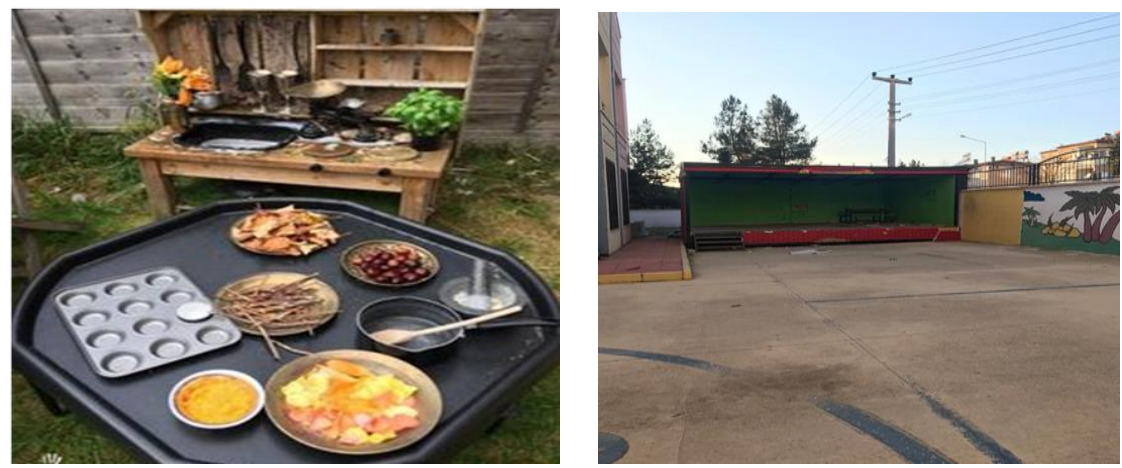

When the photographs of the sensory areas are examined, it is seen that the schools do not have these areas. Therefore, photographs of the sensory area are not available. There should be water pools and sandboxes in the school gardens for games in support of the senses. Interacting with the specified materials, children can learn and reinforce concepts such as rough-slippery, wet-dry, hard-soft, hotwarm-cold, and in this context, they can gain exploration and scientific thinking skills such as comparison and classification (Gansley, 2011).

\section{Image 7.}

A sample photo of sensory playgrounds

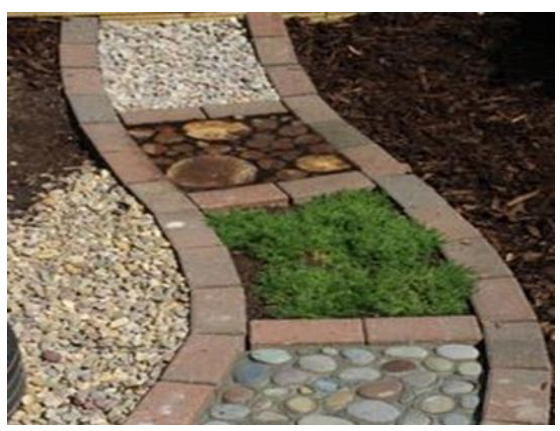

When photos of the creative areas are examined, it is observed that the tree, the playhouse and similar areas are suitable for the use of many purposes. But creative areas are found in very few of the schools.

\section{Image 8.}

A sample photo of creative playgrounds and a photo of the examined school gardens
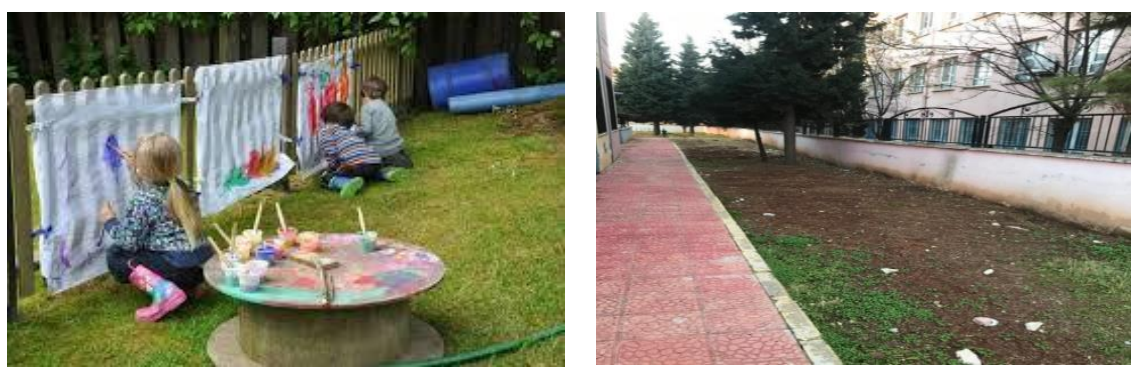
When quiet areas are examined, it is seen that schools have rest benches or different areas for resting, but these areas are limited and they are intertwined with loud areas.

Image 9.

A sample photo of quiet playgrounds and a photo of the examined school gardens
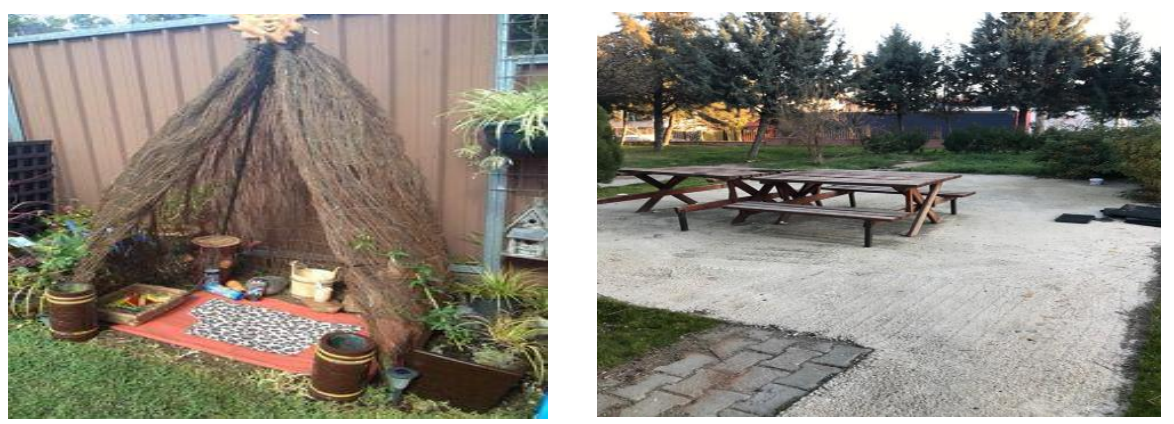

When the matrix, checklist, color location matrices and photos related to the evaluation of school gardens as a learning environment are examined, it is seen that the areas that schools have the most are physical areas and social areas, but they are not designed for their purpose in these areas. Therefore, it is necessary to reform the physical and social areas, and to bring in sensory areas, quiet areas and creative areas to schools.

\section{Conclusions}

As a result of this research, which aims to examine school gardens as a learning environment in the physical context:

- It has been observed that school gardens mostly have physical areas, have a limited number of social areas and quiet areas, and do not have creative areas and sensory areas.

- It can be said that the existing physical areas and social areas are suitable for the design of school gardens in terms of quantity, but they should be enriched with various materials in terms of quality.

- It can be said that the quiet areas in schools usually consist of rest benches, which do not allow children to be in a quiet and private area, because they are designed in conjunction with loud areas.

- It has been observed that the creative areas and sense areas have almost no place in schools.

Based on the results of the research, the following recommendations can be presented:

- Holding more scientific studies on the design or use of school gardens according to different cities, different socioeconomic levels and different types of institutions

- Instruction of school administrators, teachers and staff with in-service trainings aimed at considering and using school gardens as a learning environment

- Implementation of projects in cooperation with the National Education Directorates, Universities and Municipalities in the context of more qualified use of the existing school garden potentials

Within the scope of the TR Dizin 2020 regulations, all the regulations in the "Higher Education Institutions Scientific Research and Publication Ethics Directive" have been followed and the "Actions Contrary to Scientific Research and Publication Ethics" contained in the second part of the directive have not been carried out. 


\section{Türkçe Sürümü}

\section{Giriş}

Öğrenme ve öğretmenin gerçekleştiği, kişilerarası etkileşimleri kapsayan ortamların tümü eğitim ortamı olarak ifade edilir (Kıldan, 2007). Aktaş Arnas'a göre (2019), okul öncesi eğitim kurumları, çocukların evlerinin dışında en fazla zaman geçirdikleri mekanlardır. Tepebağ ve Arnas'a göre (2017), okul bahçeleri çocukların tüm gelişim alanlarını destekleyen becerileri kazanmasında, eğitim ve oyun ihtiyaçlarının karşılanmasında önemli bir yer tutar. Özellikle okul öncesi dönemdeki çocukların yaşları itibariyle duygusal, fiziksel, dil, bilişsel ve sosyal alanlarda gelişimsel olarak hızlı bir dönemde oldukları düşünüldüğünde, okul bahçelerinin fiziksel yapı ve özelliklerine ilişkin niteliğin daha fazla önemsenmesi gerekmektedir. Okul bahçeleri, ulaşılabilir ve yaygın öğrenme ortamları olarak, zengin uyarıcılı öğrenme fırsatları ve olanakları sunan alanlardır. Malone ve Tranter'e göre (2003), okul bahçeleri formal öğrenme için zengin bir potansiyele sahiptir.

Küçük Çocukların Eğitimi Ulusal Birliği (NAEYC), açık hava alanlarına olan ihtiyacın altını çizmekte ve eğitim programlarında yer alması gerektiğine vurgu yapmaktadır. Eğitim programının bir parçası olarak her gün kullanılması gereken okul bahçelerinin temelinde birer öğrenme alanları olduğu belirtilmektedir (Copple ve Bredekamp, 2009). UNICEF'in (2009) "çocuk dostu okullara ilişkin oluşturduğu raporda, okulun öğrencilerin yaşamında önemli bir kişisel ve sosyal çevre" niteliğinde olduğu vurgulanır.

Bu önem, çocuk dostu okulların her çocuğa fiziksel tehlikelerden arınmış, duygusal açıdan güven sağlayıcı ve psikolojik olarak gelişimlerini destekleyici olmalarını gerektirir (Başbay, 2012). Başbay'a göre (2012), " Okulun bahçesi, dar alanlar olmaktan çıkarılıp çocuğun çalışma, başarma, araştırma ve yaratma becerilerini geliştirecek her türlü sportif, sanatsal ve bahçe çalışmalarının yapılabileceği zengin bir çevre haline dönüştürülmelidir." Kytta (2004) okul bahçelerini, ideal çocuk dostu çevreye sahip olan ve bu fırsatlardan çocukların özgürce yararlanmasına imkan tanıyan alanlar olarak tanımlamaktadır.

Çok erken yaşlarda doğaya ilgi duymaya başlayan çocuklar, açık hava oyunlarında gelişimsel olarak eşsiz deneyimler yaşamaktadırlar. Çocuklar, yetişkinlikte gerekli olan bir çok beceriyi (problem çözme, sosyal yetkinlik ve yaratıcı düşünme becerileri de dahil olmak üzere) açık hava oyunları aracılığıyla öğrenebilmektedirler (Rivkin, 1995, 2000; Moore ve Wong, 1997). Çocukların kolaylıkla ve güvenilir bir şekilde erişim sağlayabildikleri tek açık alan okul bahçeleridir (Aktaş Arnas, 2019). Çocukların gelişimi açısından önemli olan bu alanlar çoğunlukla otopark için kullanılan, asfalt ya da beton ile kaplı, az da olsa bahçe görüntüsü verilmesi adına birkaç ağaç ve çiçeğin bulunduğu alanlardır. Okul bahçelerinin eğitim öğretimden uzak, gelişigüzel hazırlanmış bir mekan yerine çocukların gelişimsel açıdan desteklenebileceği açık hava oyun öğrenme alanları olarak planlanması gerekmektedir. Bu alanlar planlama açısından yanlış yönde şekillendirildiğinde çocuklar kendi ihtiyaçlarının değerli olmadığı duygusuna kapılırlar (Campbell, 2013).

Okul Öncesi Eğitim Kurumları Yönetmeliği, Madde 54'e göre; okul öncesi eğitim kurumlarında eğitimin sağlıklı ve uygun bir ortamda gerçekleştirilebilmesi için oyun alanı ile bahçenin bulunması ve amacına uygun olarak düzenlenmesi esastır. Bu düzenleme yapılırken; trafik eğitim pisti, kum havuzu, bahçe oyun araçları, ayrıca çocukların fen ve doğa çalışmaları yapabilmeleri için yeterli toprak alan bulundurulmasına özen gösterilir" (MEB Mevzuat Bankası, 2004). MEB Yönetmelikleri okul bahçelerinin, okul öncesi eğitim düzeyinde, çocuk başına $3 \mathrm{~m}^{2}$ alan, temel/orta eğitim düzeylerinde ise her çocuğa 10 $\mathrm{m}^{2}$ alan düşünülerek düzenlenmesini önermektedir. Ek olarak, çimenli/çakıl taşlı alanlar, bisiklete binilebilecek alanlar, kum havuzu, ağaçlar, toprak tepecikler ve olabilirse açık hava tiyatrosu, küçük evler, bitki bahçeleri, hayvan besleme yerleri, havuz, depo vb. ekler oluşturulması, bahçelerin etrafının tel, çit ya da duvarla korunması önerilmektedir (Poyraz ve Dere, 2003; MEB Mevzuat Bankası, 2004).

Okul bahçeleri çocukların açık alandaki ihtiyaçlarını karşılarken, çocukların hareket etmelerine olanak sunmaktadır. Böylece, çocukların günlük hareket ihtiyaçlarını karşılamalarına, enerjilerini atmalarına, 
stresin azalmasına, astım, obezite vb. hastalıklardan kurtulmalarına olanak tanımaktadır. Del Alamo'ya göre (2005), okul bahçelerinde yer alan oyun alanları oldukça önemlidir. Bu alanlar, fiziksel oyun, sosyal oyun, duyusal oyun alanları, yaratıcı oyun ve sessiz alanlar olarak tanımlanabilir.

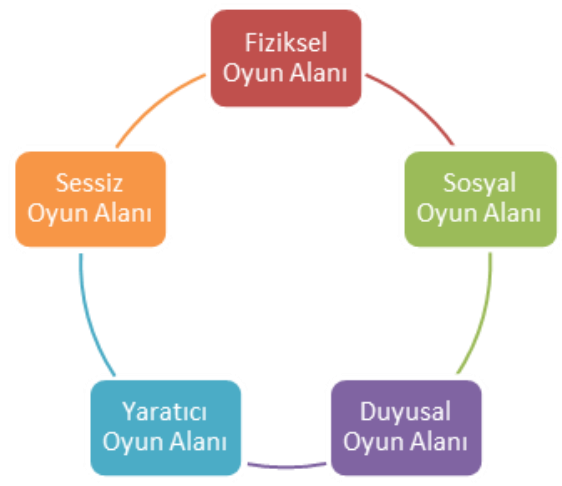

Şekil 1.

Del Alamo'nun (2005) okul bahçelerinde yer alan oyun alanları sınıflandırması

Çocuklar için açık hava alanlarının sunduğu ve en yaygın şekilde kabul edilen fayda, çocukların fiziksel gelişimi üzerine olan faydadır. Grubbels ve diğerleri. (2012) yaptıkları çalışmada, atlama araçlarının bulunduğu veya koşu için yer işaretlerinin olduğu alanlarda çocukların daha hareketli olduklarını sonucuna varmışlardır. Çocukların fiziksel gelişim alanını desteklemek için uzanma, tutma, itme, hareket, dengede durma, tırmanma, çekme, kazma, sürünme, atlama, koşma, sallanma, sıçrama, sekme, kavrama, yüzme, düşme, dökme, yükleme ve gerinmeye ihtiyaç duyulmaktadır (Campbell, 2013; Frost ve diğerleri. 2004). Çocuklara bu tür fırsatlar sağlamak, onların çevrelerindeki kaynakları değerlendirerek vücutlarını güvenli bir biçimde nasıl aktif hale getirebileceklerini öğrenmelerini sağlamaktadır (Aktaş Arnas, 2019).

Çocukların sosyal duygusal gelişim alanlarını desteklemeye fırsat verecek önemli bir potansiyele sahip ortamlardan biri de okul bahçeleridir. Çocuklar oyun oynarken birbirleriyle olan iletişimi ve etkileşimi kendiliğinden başlatırlar, kuralları kendi aralarında tartışırlar, değiştirirler ve geliştirirler. İşbirliğini ve uzlaşmayı oyunlarda ortaya çıkan çatışmalar sonucunda öğrenirler (Burdette ve Whitaker, 2005). Oyun çocuk için çok ciddi bir uğraştır ve aynı zamanda gelişim, öğrenme ve eğlence kaynağıdır (Aral ve diğerleri. 2001; Çoban ve Nacar 2006; Melendez ve diğerleri 2000). Oyun ortamına katılım sağlayan çocuğun yaşamın rollerini anlama, problem çözme, düşünme, çevre ile etkileşime girme, yardımlaşma, paylaşma ve konuşma gibi sosyal gelişimi açısından önem taşıyan becerileri edinmesine fırsat tanımaktadır (Durualp ve Aral, 2010). Oyun ortamında yaşam için gerekli olan davranışlar özellikle sosyal beceriler doğal olarak öğrenilmektedir (Darwish ve diğerleri 2001; Swindells ve Stagnitti 2006).

Duyular için bilimsel olarak ideal ortamlar; değişen ve değiştirilebilen ortamlardır. Çevrenin zengin uyarıcı ortam olması, çocukların odaklanması, dikkatini toplaması ve farkındalık geliştirmesini sağlar (Day ve Midbjer, 2007). Bunun yanında açık hava oyun/öğrenme alanlarının estetik deneyimler sunması, çocukların duyularını etkileyecek önemli bir faktördür. Sınıf içi ve sınıf dışı alanlarda (okul bahçelerinde) çocukların duyusal olarak desteklenmelerinde kum, toprak, su, doğal materyaller, oyun hamuru, kil, sabun ve köpükler gibi çeşitli malzemeler kullanılması gerekmektedir (Levne, 2006). Çocuklar oyun alanlarında yer aldıkları süreçte pek çok farklı duyularını kullanmaktadırlar (Sapsağlam, 2018). Duyu oyunları aracılığıyla bir ya da birden fazla duyusal alanda becerileri sınırlı olan çocukların farklı duyu alanlarını daha etkili kullanmaları sağlanabilmektedir (Öncü, 2020). Bu doğrultuda duyusal deneyimler aracılığıla her çocuğun var olan duyu kapasitelerini arttırabilme, başarı duygusunu tadabilmeleri ve dünyayı keşfedip bilgi altyapılarını geliştirebilmeleri mümkün olmaktadır (Snyder ve diğerleri. 2011).

Yaratıcılık, deneyimlerle ilişki kurmayı ve uyaranlara cevap vermeyi (insanlar, semboller, durumlar, fikirler, nesneler) barındıran bir süreçtir. Bu tür uyaranlar açısından doğal ortam zengin ve karmaşıktır. 
Yaratıcı alanlar çocukların risk almalarına olanak veren, aşamalı olarak zorlukları barındıran ve farklı oyun türlerini oynamaya fırsat tanıyan alanlar olarak da düşünülebilmektedir (Aktaş Arnas, 2019). Okul bahçeleri ekolojik ve pedagojik olarak değerlendirildiğinde; doğal öğrenme ortamlarından oluşmalıdır (Karakaya ve Kiper, 2013). Bu bağlamda çocukların yaratıcı yönlerini geliştirmeye yönelik çeşitli kullanımlara yer verilmelidir. Oyun olanaklarını arttırıcı zemin şekilleri ve tepecikler, güçlü ve yaratıcı oyun alanları sağlamaktadır (Casey, 2005).

Walsh (2016)'ya göre sessiz oyun alanları içerisinde; gizli, özel oyun için alanlar ve ortak kullanım alanları yer almalıdır. Arnold (1996)' göre okul bahçelerinin tasarımında ana noktalardan biri olan yapılandırılmış oyunlar, yeni oyun yaratmak, su ve kum gibi doğal elementlerle oynamak ve sessiz oyunlar için bölünmüş oyun alanlarını da içeren çeşitli aktivite alanları yer almalıdır. illgili alanın, güneşin altında olmaması, gölgelik elemanlarla korunma altına alınması önemli bir unsurdur (Del Alamo, 2005). Walden'a göre (2009) çocuklar için planlanan sessiz oyun alanları, onların sessiz merkezlerde oynamasına ve özel hayata saygı gösterilmesini gerektirdiği gibi, suç işlenmenin ya da zorbalığın önlemesini gözlemlemek için iyi bir fırsat ortamı oluşturmaktadır.

Okul bahçelerini planlanırken güvenlik seviyesinin üst düzeyde olması, sağlıklı araçlar, materyaller kullanılması ve gelişim alanlarının desteklenmesi yönünde ilkelere sahip olması gerekmektedir. Planlamalar yapılırken alanın ulaşılabilir, sürdürülebilir, pratik, anlamlı ve yaratıcı fikirler üretecek özelliklere sahip olması da göz önünde bulundurulmalıdır (Aktaş Arnas, 2019).

Çocukların açık alanlarda öğrenme ve gelişim süreçlerinin önemi düşünüldüğünde, okul bahçelerinin iyi tasarlanması gerekmektedir (Arabacı ve Çıtak, 2017; Aslan, 2010; Basar, 2020; Cooper, 2015; Wake \& Birdsall, 2016) Tüm bu ihtiyaçlardan yola çıkılarak, bu araştırmada okul bahçelerinin öğrenme ortamı olarak fiziksel bağlamda incelenmesi amaçlanmaktadır.

\section{Yöntem}

\section{Araştırmanın Modeli}

Nitel araştırma deseninde planlanan bu araştırmada, gözlem ve doküman incelemesi tekniği kullanılmıştır. Araştırma modeli şekil 2'de gösterilmiştir.

Şekil 2.

Araştırmanın modeli

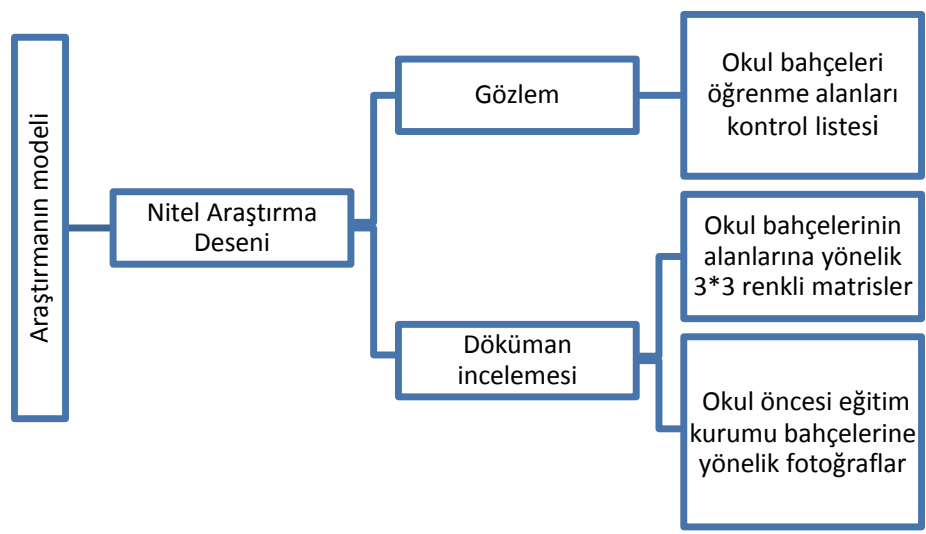

Araştırmacılar tarafından hazırlanan "Okul bahçesi öğrenme alanları kontrol listesi", okul bahçelerinin gözlemlenmesi amacıyla kullanılmıştır. Bu liste okul bahçelerine yönelik demografik bilgiler ile öğrenme ortamlarının uyarıcılığına yönelik sorulardan oluşan, Likert tipi bir listedir. İlgili liste, iki araştırmacı tarafından kullanılmış, böylece gözlemciler arası tutarılığın sağlanması ve gözlemin güvenirliliğin artması amaçlanmıştır. Bu kontrol listesinde okul bahçelerinin Del Alamo (2005) sınıflandırmasına göre (fiziksel oyun alanları, yaratıcı oyun alanları, sosyal oyun alanı, duyusal oyun alanları ve sessiz alanlar) değerlendirilmesi sağlanmıştır. 
Araştırmada fotoğraflar ve renkli matrisler, doküman incelemesi tekniğinde kullanılmıştır. Fotoğraflar, 27 okul öncesi eğitim kurumuna ait okul bahçelerini göstermektedir. Fotoğraflar, araştırmacılar tarafından gözlem anında çekilmiş, fiziksel oyun, yaratıcı oyun, sosyal oyun, duyusal oyun alanları ve sessiz alanlar gibi birçok farklı alanı içermesine özen gösterilmiştir.

Okul bahçelerinin alanlarına yönelik renkli matrisler, $3 * 3$ matris olarak araştırmacılar tarafından geliştirilmiş, Başbay (2012) tarafından geliştirilen "Okul bahçelerinin konum matrisleri"nden bu bağlamda yararlanılmıştır. "Okul bahçelerinin alanlarına yönelik renkli matrisler", her bir öğrenme alanı için farklı renkler ile kodlanarak oluşturulmuştur.

\section{Katılımcılar}

Araştırmanın çalışma grubunu, Gaziantep illi Şahinbey ve Şehitkâmil ilıçelerine bağlı 27 okul öncesi eğitim kurumu oluşturmaktadır. Tablo 1'de okullara yönelik demografik bilgiler yer almaktadır.

Tablo 1.

Araştırmada yer verilen okullar hakkında demografik bilgiler

\begin{tabular}{ll|l}
\hline & Kamu & Özel \\
\hline Şahinbey & 7 & 3 \\
Şehitkamil & 12 & 5
\end{tabular}

Kurum türüne göre dağılımda: 27 okul öncesi eğitim kurumunun \%77,8'inin Milli Eğitim Bakanlığı'na bağıı bağımsız anaokulları ve \%22,2'sinin özel ana okullardan oluştuğu söylenebilir.

\section{Kullanılan Veri Toplama Araçları}

Araştırmada veri toplama aracı olarak, araştırmacılar tarafından geliştirilen, "Okul bahçeleri öğrenme alanları kontrol listesi", 3*3 okul bahçelerindeki alanları gösteren renkli matrisler ile okul bahçelerindeki farklı öğrenme alanlarını içeren (fiziksel oyun alanı, sosyal oyun alanı, yaratıcı oyun alanı, duyu oyun alanı, sessiz alan) fotoğraflar kullanılmıştır.

"Okul bahçeleri öğrenme alanları kontrol listesi” araştırmacılar tarafından ilgili alan yazından faydalanılarak oluşturulmuştur. Okul bahçeleri öğrenme alanları kontrol listesi 53 maddeden oluşturulmuştur. Kontrol listesinde yer alan 53 madde Del Alamo'nun (2005) sınıflandırılması dikkate alınarak yeniden düzenlenmiş sınıflandırma dışında kalan 9 maddenin kontrol listesinden çıkarılması uygun görülerek 44 madde ile formun son hali verilmiştir. İki bölümden oluşan kontrol listesi, demografik bilgileri ve öğrenme ortamlarının uyarıcılığına ilişkin maddeleri içermektedir. Her bir madde 0-5 arası puanlamadan oluşan Likert tipi bir derecelendirme aracı olarak düşünülmüş, araştırmacılar tarafından 0-5 arası puanlanmıştır. Bu puanlamada "en az"dan "en çok"a doğru bir değerlendirme yapılmıştır. Bu bağlamda, Del Alamo (2005) sınıflandırmasına göre (fiziksel oyun alanları, yaratıcı oyun alanları, sosyal oyun alanı, duyusal oyun alanları ve sessiz alanlar) değerlendirilmesi amaçlanmıştır. Bu amaçla, kontrol listesi iki araştırmacı tarafından ayrı ayrı doldurulmuş ve araştırmacılar arası tutarlılığın hesaplanması ve araştırmanın verilerinin güvenirliliğin artırılması da sağlanmıştır.

Okul bahçeleri öğrenme alanları kontrol listesi tablo 2'de gösterilmektedir. 
Tablo 2.

Okul bahçeleri öğrenme alanları kontrol listesi

Ölçüt
Tırmanma, kayma vb fiziksel aktivitelere uygun ekipmanlar vardır.
Gürültüye ve özgürce koşabilmeye uygundur.
Çocukların kendilerinin riskleri ve zorlukları fark edebilecekleri düzenlemeler bulunur.
Tırmanmaya uygun, mevsimsel değişimlerin ve ışı oyunlarının gözlenebileceği ağaçlar
vardır.

Taş ya da odun parçalarından patikalar vardır.

Bisiklet ya da tekerlekli oyuncak kullanımı için uygundur.

Tırmanma, yuvarlanma, kayma aktiviteleri için uygundur.

Tekerlekli araçların kullanımı için yollar vardır.

Fiziksel

Sadece tahtalarla çalışabileceği düzenlemeler vardır.

Alan büyüklüğü çocuk sayısına uygundur.

Çocuğun yaşına, boy ve kilosuna uygun oyun ekipmanlarını içerir.

Aktiviteler ile birçok motor davranış arasındaki akıcılığı sağlayacak özelliktedir.

Fiziksel aktivitelere olanak tanır.

Çocuk tarafından başlatılan oyunlara elverişlidir.

Bir hedefe yönelik faaliyeti özgürce seçme, sorgulamalar yapma olanağı sunar.

Aşırı uyarıcı olmayan oyuna davetkar bir ortamdır.

Dramatik oyun için düzenlemeler vardır.

Çeşitli oyunlar ile öğrenmeyi sağlar.

Diğer çocuklarla sosyal etkileşimde bulunmaya uygundur.

Merak duygusunu geliştirir.

Kendini tanıma ve özgüven oluşmasını destekler.

Risk almayı ve zorluklarla başa çıkmayı öğretir.

Duyusal deneyim alanları vardır.

İklimsel değişikliklerin gözlenebileceği bir ortamdır.

Ağaçlar, çiçekler, çalılar, meyveli bitkileri olan güzel bir bahçesi vardır.

Taşınabilir özellikte su ve kum oyun havuzu vardır.

Doğa ile etkileşim kurmaya uygundur.

Rüzgarı hissedebilecekleri çanlar, rüzgar gülleri, fırıldaklar vardır. 
Su bitkilerini, meyveleri, farklı kokulara sahip bitkileri incelemeye uygundur.

Çocukların elleri ve parmakları ile kullanabilecekleri malzemeler bulunur.

Geniş bir kum havuzu vardır.

Doğa olaylarının çevresini nasıl değiştirebileceğini anlama fırsatları sunar.

Estetik duygusunu kazandırır.

Farklı bitkileri içeren alanlar vardır.

Farklı dokularda hem doğal hem de insan yapımı malzemeler vardır.

Yeniliğe ve çeşitliliğe uygun alanlar vardır.

Sanat etkinlikleri uygulanabilir.

Çok çeşitli aktivite türlerine olanak sağlar.

Beden, uzay, zaman ve yön farkındalığı öğreten zengin duyusal deneyimler sağlar.

Yaratıcılığı geliştirir.

Öğrenmeyi destekleyen zengin uyarıcılar bulunur.

Dinlenme için banklar vardır.

Güneşli ve gölgelik alanları içerir.

Sessizlik ve dinlenme için alanlar vardır.

Okul bahçelerinin öğrenme ortamı olarak değerlendirilmesinde renkli matrisler kullanılmış, bu matrislerde her renk bir veya birkaç öğe ile ilişkilendirilmiştir. 3*3 okul bahçelerindeki alanları gösteren renkli matrisler, okul bahçelerinde yer alan farklı alanları görsel olarak tanımlamayı amaçlamıştır. Bu nedenle yeşil alanlar yeşil, beton alanlar gri, toprak alanlar kahverengi vb. gibi her alana özgü bir renk kodlanmış, bu kodlamalar doğrultusunda araştırmacılar tarafından 27 okul bahçesini betimleyen 27 renkli matris oluşturulmuştur. Renk kodlamasında var olan alanları tanımlamasına özen gösterilmiştir. Örneğin toprak alanlar kahverengi, beton alanlar gri, çimlik alanlar yeşil olarak kodlanmıştır. Bu bağlamda renkli matrislerde kullanılan renk kodları Şekil 3'de gösterilmektedir.

\section{Şekil 3.}

\section{Matrislerde kullanılan renk kodları}
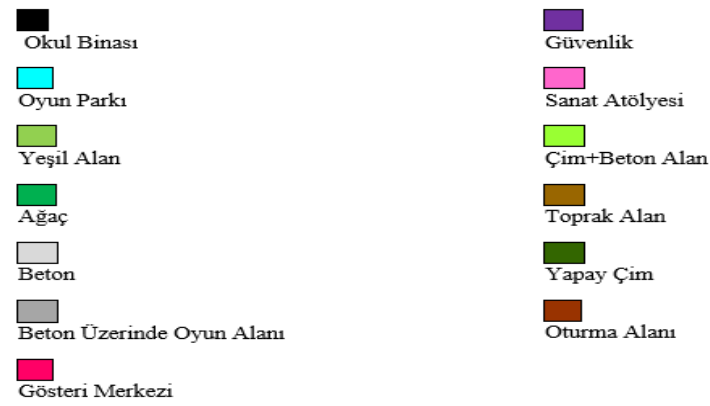

"Okul bahçelerindeki farklı öğrenme alanlarını gösteren fotoğraflar", okul bahçelerinin gözlemlenmesi amacıyla araştırmacılar tarafından çekilmiştir. Bu fotoğraflar, 27 okul öncesi eğitim 
kurumunun bahçelerini göstermektedir. Araştırmacılar tarafından diğer dokümanları desteklemeleri ve somutlaştırmaları amacıyla tercih edilmiştir.

\section{Veri Analizi}

"Okul bahçeleri öğrenme alanları kontrol listesi” ne ilişkin veriler, yüzdelik ve frekans dağı̆ımları ile analiz edilmiştir. Ayrıca, "Okul bahçesi öğrenme alanları kontrol listesi", renkli matrisler ve fotoğraflar ise içerik analizi ile değerlendirilmiş, bu bağlamda temalar oluşturulmuş, temalara yönelik bulgular alan yazın ile tartışıımışıı.

\section{Bulgular ve Yorum}

Araştırmanın bulguları "Okul bahçeleri öğrenme alanları kontrol listesi" için yüzdelik hesaplamaları; Okul bahçesi öğrenme alanları kontrol listesi" öğrenme alanlarına yönelik renkli matrisler ve fotoğrafların içerik analizine ilişkin tema ve alt temalardan oluşmaktadır.

\section{Kontrol Listesine ilişkin Bulgular}

"Okul bahçeleri öğrenme alanları kontrol listesi"nden elde edilen bulgular Alamo (2005) sınıflandırılması dikkate alınarak 5 ana temada ele alınmış, bu temalar doğrultusunda içerik analizi yapılmıştır. Bu analizden elde edilen bulgular şöyledir:

\section{Tablo 3.}

Alanlara Göre Kontrol Listesinde Yer Alan Maddelerin Yüzdelik Dağılımı

\begin{tabular}{cccccccc}
\hline Alanlar & $\begin{array}{c}\text { Alanlara Göre Kontrol } \\
\text { Listesinde Yer Alan Madde } \\
\text { Sayısı }\end{array}$ & $\mathbf{0}$ hiç & $\mathbf{1}$ çok az & $\mathbf{2}$ az & $\mathbf{3}$ orta & $\mathbf{4}$ iyi & $\mathbf{5}$ çok iyi \\
\hline Fiziksel Alan & 13 & $\% 32,7$ & $\% 18,8$ & $\% 16,2$ & $\% 14,2$ & $\% 10,5$ & $\% 8,5$ \\
Sosyal Alan & 9 & $\% 31,4$ & $\% 29,1$ & $\% 19,4$ & $\% 15,2$ & $\% 9,7$ & $\% 7,4$ \\
Yaratıcı Alan & 6 & $\% 25,9$ & $\% 27,6$ & $\% 25,9$ & $\% 13,5$ & $\% 7,4$ & 0 \\
Duyu Alan & 13 & $\% 34,4$ & $\% 19,3$ & $\% 22,7$ & $\% 11,3$ & $\% 6,5$ & $\% 4,2$ \\
Sessiz Alan & 3 & $\% 27,1$ & $\% 19,7$ & $\% 20,9$ & $\% 11,1$ & $\% 12,3$ & $\% 8,6$ \\
\hline
\end{tabular}

Tablo 3'e göre, fiziksel alanın \%8.5 oranında çok iyi, \%10.5 oranında iyi, \% 16.2 oranında az, \% 18.8 oranında çok az ve \%32.7 oranında ölçütleri karşıladığı, \%32.7sinin ise ölçütleri hiç karşılamadığı görülmektedir. Illgili alan yazın fiziksel alanların çocukların hareket ihtiyaçlarını karşılamada, sağlıklı ve iyi olma halini desteklemede ne kadar önemli olduğunun altını çizmektedir. Hareket ve fiziksel aktiviteye katııım, çocuğun büyüme ve gelişmenin daha iyi olması, aktif yaşam biçiminin kazandırılması, ileride oluşabilecek hastalık risklerinin azaltılması ve aşırı kilo alımının önlenmesi için son derece önemlidir (Çelik ve Şahin, 2013). Karadağ, Mutlu ve Sayın'a göre (2012) oyun, çocuğun beden, zihin, psikoloji ve sosyal açıdan sağılıklı gelişebilmesini sağlayan temel bileşenlerdendir. Tandoğan'a göre (2016), çocuğun doğal ihtiyacı olan koşma, tırmanma, atlama, duvar üzerinde yürüme, suyla, kumla, toprakla oynama gibi aktiviteler çocuğun fiziksel gelişimini desteklemekte, bedenini ve sınırlarını öğrenmesini ve yeteneklerinin farkına varmasını sağlamaktadır. Okul bahçelerinin fiziksel aktivitelere uygun ekipmanlar (oyun parkları, grup oyunlarına yönelik zemin tasarımları gibi) içerdikleri ancak bu ekipmanları tek düze ve sınırlı oldukları görülmüştür. Bu nedenle çocukların farklı fiziksel aktivitelere katıımını destekleyecek nitelikte ekipmanların sağlanması gereklidir. 
Kaçan, Halmatov ve Kartaltepe (2017), okul bahçelerinin sıklıkla oyun, hareket, fen ve alan gezisi etkinlikleri için kullanıldığını ifade etmektedir. Bununla birlikte ilgili alan yazında okul bahçelerinin:

- Sanat, müzik ve gösteri çalışmaları alanı (kameliye tipi),

- Fen eğitimi çalışmaları alanı (bitki yetiştirme, deney, gözlem, sulama),

- Küçük hayvanat bahçesi (tavuk, köpek tavşan gibi hayvanların bakımı, beslenmesi),

- Trafik kurallarını öğrenme alanı, çocukların sergi alanı, kum havuzu, aktif ve serbest

- Etkinlikler için çim alanı (koşma, top oynama, zıplama, geleneksel çocuk oyunları vs.),

- Öğretmenlerin ve ebeveynlerin çalışma, deney, gözlem ve oturma alanı bulunmasının gerektiği vurgulanmaktadır.

(Collyer ve Irvine, 2001; Fisman, 2001; Pickard, 2002; Corson, 2003; Özdemir ve Yılmaz, 2009; Aktaran: Kaçan, Halmatov ve Kartaltepe, 2017, Başar, 2020)

Tüm bu alanlar, farklı ve çeşitli aktivitelere olanak sağlamaktadır. Ancak araştırmanın bulguları, okul bahçelerinin sınırlı düzeyde çeşitlilik içerdiğini gösterir niteliktedir. Okul bahçeleri farklı ve çeşitli etkinliklere yer vermek suretiyle farklı ilgi alanları, yetenekleri ve deneyimleri olan çocuklara hitap edebilir.

Okul bahçelerinin öğrencilere fiziksel aktivite ve oyun imkânı sağlayan sosyal mekânlar olarak düzenlenmesi gerekmektedir (Özdemir ve Yılmaz, 2009). Okullarda oyun alanlarının planlanması öğrencilere koşma, atlama, zıplama, fırlatma, sallanma, tırmanma, yakalama gibi çeşitli etkinliklere olanak vermekte ve hareketlerin sonucu olarak fiziksel aktivite düzeyleri gelişmektedir (Vural ve Yılmaz, 2016). 1994 yılında 21.yy okul fonu (The 21st Century School Fund) programı Amerika'da güvenli, sağlıklı ve eğitimi destekleyen nitelikli okulların oluşumu için kurulmuştur. Uygulamaya yönelik çalışmalar yapan bu kuruluşun 2011 yılında yayınlamış olduğu rapora göre; çocuklar günde minimum bir saat fiziksel gelişimlerini desteklemek adına ilgili alanda gerçekleştirilecek aktivitelere intiyaç duymaktadırlar. Çocukların ihtiyaçlarına cevap vermek ve onları desteklemek için okul bahçeleri içinde bulundurulması gereken oyun ve spor alanları ile ilgili fiziksel etkinliklere yer verilmesi gerekmektedir (21st CSF, 2011).

Ural’a göre (2007) “ çevre ne kadar zengin ve ilginç uyarıcılar sunarsa çocukların öğrenme fırsatları o kadar artar. Eğitim kurumlarının tümünde fiziksel çevre, bireyin davranışı ve gelişimi üzerinde etkilidir, özellikle çocuğun fiziksel, zihinsel ve psikososyal gelişiminin çok hızlı olduğu ve bu gelişim alanlarının biçimlendirdiği okul öncesi eğitim kurumlarında fiziksel çevre daha da önem kazanmaktadır." Eğiticinin verimli olabilmesi ve programın istenildiği şekilde uygulanabilmesi için fiziksel ortamın uygun, donanımın da yeterli olması gerekmektedir. Ortam, çocuklar öğrenmek için neye ihtiyaç duyarsa onu sağlamalıdır" (Aktaran, Başbay, 2012).

Okul bahçeleri, çocukların oyun ihtiyacını güvenilir, sağlıklı ve zengin bir şekilde karşılayabilecek nitelikte olmalıdır. Araştırmanın bulguları, okul bahçelerinin sınırlı düzeyde oyun ihtiyacını karşıladıklarını göstermektedir. Çocuğun yaşamında büyük öneme sahip oyunun, yine çocuğun yaşamında çok önemli bir yeri olan okulda karşılanması, özellikle okulların açık alanları olarak okul bahçelerinin bu amaçla kullanılması gereklidir. Bu nedenle, okul bahçelerinin çeşitli oyunlara yer verecek nitelikte yeniden düzenlenmesi gerekir.

Louv (2005), "Doğadaki son çocuk" adlı kitabında çocukların özgürce koşmaya ve oyun oynamaya ihtiyaçları olduğunu, doğanın bunun için çok önemli bir gereklilik olduğunun altını çizmekte, kentleşme ile bu özgürlüklerin sınırlandırıldığı veya sona erdiğini ifade etmektedir. Bununla birlikte, yapılan araştırmalar, özellikle son yirmi yıl içerisinde okul çağı çocuklarının fiziksel aktivite düzeylerinin azaldığını göstermektedir (Dyment, Bell \& Lucas, 2009; Cengiz ve Ince, 2013). Aksu ve Demirel'e göre (2011), kentleşme nedeniyle azalan açık mekanlar, çocukların oyun alanlarını sınırlandırmaktadır. Çocuğun bütünsel gelişimini destekleyen oyun ortamının okul bahçelerinde sağlanması gerekir. Bu nedenle okul bahçelerinde yer alan alanların çocukların fiziksel ve zihinsel yönden aktif olmalarını destekleyecek büyüklükte ve nitelikte olması önemlidir. Çocuklar için en kolay ulaşılabilen açık öğrenme ortamları olan 
okul bahçeleri, bu bağlamda çocuğu destekleyebilecek alanlar olabilir. Ancak araştırmanın bulguları okul bahçelerinin bu bağlamda sınırlı kaldıklarını göstermektedir.

Tablo 3'e göre, sosyal alanın \%7.4 oranında çok iyi, \%9.7 oranında iyi, \% 15.2 oranında orta, \% 19.4 oranında az ve \%29.1 oranında çok az ölçütleri karşıladığı, \%31.4sinin ise ölçütleri hiç karşılamadığı görülmektedir. İlgili alan yazın sosyal alanların çocukların kendilerini ve başkalarııı tanıma, kendine güvenme ve kendini ifade etme, toplum yaşamına uyum sağlama ve sosyalleşmede ne kadar önemli olduğunun altını çizmektedir.

Başbay (2012), çocuk dostu okulların çocuğun kendisine ve çevresine güven duymasına olanak sağladığııı ifade etmektedir. Araştırmanın bulgularına göre 27 okuldan sadece 8 'i çocuğun kendisini tanımasına ve özgüven duymasına olanak sağlayacak niteliktedir. 17 okul ise bu özgüveni destekleyecek koşullara sahip değildir. Bu durumda okul bahçeleri düzenlenirken, okul bahçelerinin sosyal öğrenme ortamı olarak düşünülmesi ve çocuğun kendini tanıması, bağımsız hareket edebilmesi ve özgüven duyacağı etkinlikleri özgürce yapabileceği ortamlar olarak tasarlanmaları son derece önemlidir.

Okul bahçeleri sosyal etkileşim, doğal çevre ile etkileşimi sağlama, fiziksel aktivite, yaratııılık ve problem çözme becerilerini geliştiren alanlardır (Wood ve Martin, 2000). Çocukların akranlarıyla iletişimi başlatma ve sürdürmesi olarak tanımlanan sosyal etkileşim, okul bahçelerinin sosyal öğrenme ortamı olarak düzenlenmesi ile desteklenebilir. Araştırmanın bulgularına göre, okul bahçeleri sosyal etkileşimi belirli düzeyde desteklemektedir. Bu nedenle okul bahçelerinin sosyal etkileşimi destekleyecek, grup oyunlarının oynanmasını teşvik edecek şekilde geliştirilmesi gereklidir.

Uzut'a göre (2020), okul bahçelerinin çocuğa uygun ekipmanlar içermesi çocuğa rahat ve güvenilir bir alan sunar. Böylece çocuğa bu alanda pozitif mesajlar verilir ve çocuk kendini rahatlıkla ifade edebileceği ve güvenebileceği bir öğrenme ortamında bulunur.

Tablo 3'e göre, yaratıı alanın \%7.4 oranında çok iyi, \%13.5 oranında iyi, \% 25.9 oranında orta, \% 27.6 oranında az ve \%25.9 oranında çok az ölçütleri karşıladığı, hiçbirinin çok iyi ölçütünü karşılamadığı görülmektedir. İlgili alan yazın yaratıcı alanların çocukların kendilerini yaratıcı yollarla ifade etme, inovatif beceriler gösterme ve yeniliklere açık olma konusunda ne kadar önemli olduğunun altını çizmektedir.

MEB (2013) okul öncesi eğitim programı́na göre, "Yaratıcılı̆ı̆n Geliştirilmesi Ön Plandadır: Çocukların öğrenme gereksinimleri ve öğrenme stillerine uygun ortamlarda kendilerini farklı yollarla ve özgün bir biçimde ifade etmeleri için gerekli olan fırsatlar yaratılmalıdır. Bu amaçla öğrenme sürecinde farklı materyaller, farklı yöntem ve tekniklerle çocukların bireysel farklılıkları desteklenmelidir".

Araştırmaya katılan okulların \%77.8'i M.E.B'na bağlı bağımsız anaokulları olmasına ve MEB(2013) okul öncesi eğitim programı yaratıcılığı ön planda tutmasına rağmen, araştırmanın bulguları Gaziantep ilinde kapsama alınan okul bahçelerinin yaratıcılığı desteklemediğini göstermektedir. Bu durumda, okul bahçelerinde yaratıc materyaller bulundurma, yaratıcı ortamlar oluşturma, var olan ortamları yaratıcı şekillerde kullanma çok önemlidir.

Illgili alan yazın çocukların yaratıclığında "kontrollü risk" almalarının önemine değinmektedir. Kalburan'a göre (2014), dış mekanda oyun çocukların çevrelerini keşfetmeleri, yaralanmaktan kaçınmayı öğrenmeleri, bedenlerinin yapabileceğini öğrenmeleri yoluyla riskleri fark etmeleri, değerlendirmeleri, mücadele etmeleri açısından çok önemli fırsatlar sunar. Bundy, Luckett, Tranter, Naughton, Wyver, Ragen ve Spies (2009), çocukların hiç risk almamasının aslında risk olduğunu ifade etmekte, çocukların başa çıkabileceği riskler almalarının önemine değinmektedir. Bu nedenle okul bahçeleri düzenlenmesi ve kullanımı sürecinde çocukların başa çıkabilecekleri riskleri güvenli bir ortamda almaları ve deneyimlemelerine olan ihtiyaç fark edilmeli ve bu ihtiyacı karşılamaya yönelik fiziksel ve sosyal düzenlemeler yapılmalıdır. 
Nur'a göre (2019) çocukların tehlikeli olmamak koşuluyla risk almaya ve meydan okumaya ihtiyaçları vardır. Böylece çocuklar, riskleri etkili bir şekilde yönetme becerisi kazanabilir ve kendilerine olan güvenlerini test edebilirler. Alat, Akgümüş ve Cavalı'ya göre (2012) risk alma, yetişkinlikte hayata uyum sağlamayı kolaylaştıran riskli durumlarla baş etme, kendi karar ve davranışlarının sonuçlarından sorumlu olma, kendi beceri ve kapasitesinin sınırlarını öğrenme gibi erken yaşta kazanılması gereken oldukça önemli becerileri kazanmayı sağlar. Bu nedenle okul bahçelerinin "kontrollü risk" "makul düzeyde risk" almaları için çocuklara fırsat sağlaması önemlidir. Araştırmanın bulguları okul bahçelerinin risk almaya yönelik yeniden düzenlenmesine ihtiyaç duyduklarını göstermektedir.

Çukur ve Delice'ye göre (2011), okul bahçelerinin farklı dokularda malzemeler içermesi çocukların yaratıcılığı desteklemekte ve farklı oyun türlerine olanak sağlamaktadır. Ayrıca çocuğun algı gelişimine yardımcı olmaktadır. Ayrıca, farklı ve zengin dokular ile oluşturulan mekanlar, çocukların renk, biçim, perspektif gibi birçok alanı içeren görsel algılarını da beslemektedir. Bu nedenle farklı dokularda malzemelerin, okul bahçelerinde bulunması desteklenmelidir. Ancak araştırmanın bulguları okul bahçelerinin bu bağlamda sınırlı kaldıklarını göstermektedir.

Tablo 3'e göre, duyu alanının \% 4.2 oranında çok iyi, \%6.5 oranında iyi, \% 11.3 oranında orta, \% 22.7 oranında az ve \%19.3 8oranında çok az ölçütleri karşıladığı, \%34.4ünün yetersiz ölçütünü karşıladığı görülmektedir. İlgili alan yazın duyuların erken çocukluk dönemindeki önemine vurgu yapmakta ve duyusal deneyimlerin açık mekanlarda ve okul bahçelerinde desteklenebileceğinin altını çizmektedir.

Cooper (2005) duyuların çocukların gelişiminde önemli bir yere sahip olduğunu belirtmektedir. Çocuklar yaşamlarının ilk yılından itibaren dünyayı ve çevrelerini bedenleri aracılığıyla algılar ve tanımaya başlarlar. Doğumla birlikte henüz bedenlerinin hareket koordinasyonunu net kazanmamış ya da dil edinimini kavramamışken, duyu organları yardımıyla yaşadıkları çevreyi anlamaya çalışırlar. Bu duyulardan en önemlilerinden birisi de dokunma duyusudur. Çocuklar dokunarak, hareket ederek diğer duygularını geliştirmektedirler. Montessori, Frobel, Piaget, Rousseau gibi erken çocukluk eğitiminin temellerini atan eğitimciler de hareket etmenin, duyuları geliştirmenin önemi üzerinde durarak açık hava oyunlarının çocukların duyusal gelişimlerini desteklediğini vurgulamışlardır (Bilton, 2010). Dış mekan oyunları çocukların duyularını desteklemek açısından önemli fırsatlar sunmaktadır. Uslu ve Shakouri (2012), çocukların farklı duyularına hitap eden ve onların gelişimlerini destekleyen, farklı kokuları olan bitkilerin olduğu, farklı yapılarda ve dokularda materyallerin bulunduğu ortamlarda bulunmaları gerektiğini ifade etmişlerdir. Çelik'e göre (2012) bahçeler, okul öncesi eğitim kurumlarında öğrencilerin, canlılar dünyasının elemanları ile duyusal deneyimler kazanmasını sağlayacak olan alanlardır. Huz ve Kalburan'a göre (2017), okul bahçeleri tüm duyuları harekete geçiren, deneye, keşfe, araştırmaya dayalı çevreyle iç içe bir öğrenme ortamı sunar. Okul bahçelerinin duyusal deneyim alanları içermesine yönelik bulgular, okul bahçelerinin bu bağlamda sınırlı kaldıklarını göstermektedir.

Tablo 3'e göre, sessiz alanının \% 8.6 oranında çok iyi, \%12.3 oranında iyi, \% 11.1 oranında orta, \% 20.9 oranında az ve \%19.7 oranında çok az ölçütleri karşıladığı, \%27.1'inin yetersiz ölçütünü karşıladığı görülmektedir. İlgili alan yazın sessiz alanların çocukların dinlenmelerine olanak sağladığını ve çocukların gelişimi açısından gerekli olduğunu ifade etmektedir.

Çocukların hareket etmelerini sağlayan alanlar kadar onların dinlenmeleri, çevrelerini gözlemlemeleri, oyun alanlarını keşfetmeleri için sessiz, sakin alanlar da önemlidir. Çocukların yalnız kalmaları onların bağımsızlaşma ve kendi kararlarını vermelerini de desteklemektedir. Bu alanlar öğretmenlerin de çocukları gözlemlemeleri için önemli fırsatlar sağlamaktadır. Bu alanların da tamamen boş bırakılması yerine, su ve kum havuzu, minderler gibi materyallerle zenginleştirilmesi çocuklar için ortamı daha cazip hale getirmektedir. Ek olarak bu alanların gölgelik bir alana yapılandırılması gerekmektedir (Del Alamo, 2005). Pestalozzi, sınıfı çocuğun oturma odasına; okulun bahçesini de onun dinlenme alanına benzetmektedir (Gollwitzer vd, 1959: 5; akt. Başar, 2020). Pestalozzi bu sözüyle iç mekanın önemli olduğu kadar dış mekanın da önemli olduğunu vurgulamaktadır. Çocuklar dış mekanda nitelikli vakit geçirdiklerinde iç ve dış dünya hakkında bağlantıyı daha rahat kuracak, günlük yaşamı daha iyi anlamlandıracak ve bunu duyuları aracılığıyla yapacaklardır. Bu noktada dış mekanda çocukların 
duyularının beslenmesi ve desteklenmesi önemli bir unsur olarak karşımıza çıkmaktadır (Başbay, 2012). Vural ve Yılmaz'a göre (2018) okul bahçeleri farklı ihtiyaçları karşılayacak nitelikte tasarlanmalı ve düzenlenmelidir. Sessiz alanlar, çocuklara dinlenme fırsatı oluşturduğundan önemlidir ve okul bahçelerinde bulunması gereken alanlardan biridir. Ancak araştırmanın bulguları okul bahçelerinin bu bağlamda yetersiz olduğunu gözler önünde sermektedir.

\section{Renkli Matrislere ilişkin Bulgular}

Okul bahçelerinin 3*3lük matrisler halinde hazırlanmış, bu aşamada Başbay (2012) matris oluşumuna ilişkin süreçleri temel alınmıştır. Başbay'ın (2012) geliştirdiği 3X3'lük oluşturulmuş konum matrislerinden yararlanılmıştır. Okul bahçelerinin okul binalarına göre konumlarının belirlenmesi amaçlamış ve bu matriste, okuldaki kapalı (okul binası) ve açık alanların (bahçe, oyun alanı) belirlenmesi hedeflenmiştir.

\section{Şekil 4.}

\section{Örnek Matrisler}
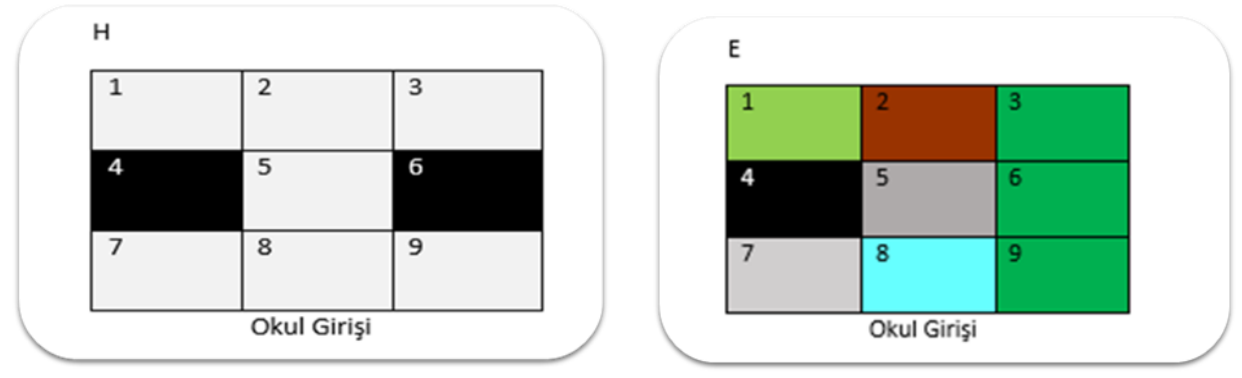

Okul bahçelerinin öğrenme ortamı olarak değerlendirilmesinde renkli matrisler incelendiğinde, fiziksel alanların ve sosyal alanların yaratıcı alan, duyu alanları ve sessiz alanlara göre daha fazla konumlandırıldığı görülmektedir.

Fiziksel alanların büyüklüğü ve yerinin okullara göre değiştiği, nicelik olarak okulların sıklıkla büyük okul bahçelerine sahip oldukları, bu bahçelerde beton alanların yoğunlukta olduğu görülmektedir. Fiziksel alanlarda yapılandırılmış oyun parklarına okulların büyük çoğunluğunda yer verildiği ve oyun parklarının sıklıkla ön okul bahçelerinde konumlandııılığı, sınırlı sayıda okulda yan ve arka bahçenin kullanıldığı görülmüştür.

Sosyal alanların, grup oyunlarında kullanılmak üzere tasarlandıkları, beton alana çizilen grup oyunlarının genellikle kullanıldıkları görülmektedir. Bununla birlikte, sosyal alana yönelik yeșil alanlar, toprak alanlar vb. alanların sınırlı olarak yer bulduğu da söylenebilir. Bu bağlamda sosyal alanları içeren matrisler sıklıkla gri renk tonlarından oluşmaktadır. Sosyal alanların okul bahçelerindeki konumu değişkenlik göstermek ile birlikle, sıklıkla okul bahçesinin ön tarafında bulundukları söylenebilir. Bu durum sosyal alanların görülebilen ve kontrol edilebilen, güvenilir ortamlar olması yönünde bir amaç ile yapılmış olabilir.

Yaratıcı alanlar incelendiğinde, okulların genellikle yaratııı alanlara yer vermedikleri, çok az okulda yaratıcilığı destekleyen sanat alanlarına ve ya zengin uyarıcılı ortama yer verildiği görülmüştür. Yaratıcı alanlar renkli matrislerde sanat alanları, gösteri merkezleri vb alanları içerdiğinden pembe renk tonları ile gösterilmiştir. Var olan sınırı sayıdaki yaratıcı alanın okul girişinde konumlandırıldığı görülmüştür.

Duyu alanları incelendiğinde, duyu alanlarının okul bahçelerinde yer almadığı, bu yönde desteklenmeye intiyaç olduğu görülmektedir. Duyu alanları okul bahçelerinde yer bulmadığından, konumu ile ilgili bir bulguya da rastlanmamıştır. Ancak okul bahçelerinde bulunulan toprak alanlar, yeşil alanlar ve beton alanlar duyu alanlarına dönüştürülebilir. 
Sessiz alanlar incelendiğinde, okulların genelinde dinlenme banklarının kullanıldığı ancak çocukların sessiz alanda kalmaları ve bu alanda kitap okuma, dinlenme vb. ihtiyaçlarını karşılamaya uygun ortamların olmadığı görülmektedir. Var olan sessiz alanların sıklıkla oyun parkı gibi sesli alanlar ile iç içe konumlandırıldığı görülmüştür.

\section{Fotoğraflara ilişkin Bulgular}

Okul bahçelerinin öğrenme ortamı olarak değerlendirilmesinde okul bahçelerinin fotoğraflarından da yararlanılmıştır. Okul bahçelerinde yer alan alanlar (fiziksel alan, sessiz alan, duyu alanı, yaratıcı alan ve sosyal alan) bu fotoğrafların analizi ile de desteklenmiştir.

Fotoğraflar incelendiğinde okul bahçelerinin fiziksel alan olarak kullanımında beton alanların sıklıkta olduğu, yeşil alanların daha az olduğu, hareketi desteklemeye yönelik salıncak, kaydırak vb. oyun araçlarına yer verildiği görülmektedir. Bununla birlikte bazı okullarda oyun evi, tırmanma alanı, vb. alanlar bulunmaktadır ancak bu araçların bulunduğu okullar oldukça sınırlıdır.

\section{Şekil 5.}

Fiziksel oyun alanlarına yönelik örnek fotoğraf ve incelenen okul bahçelerine ait fotoğraf
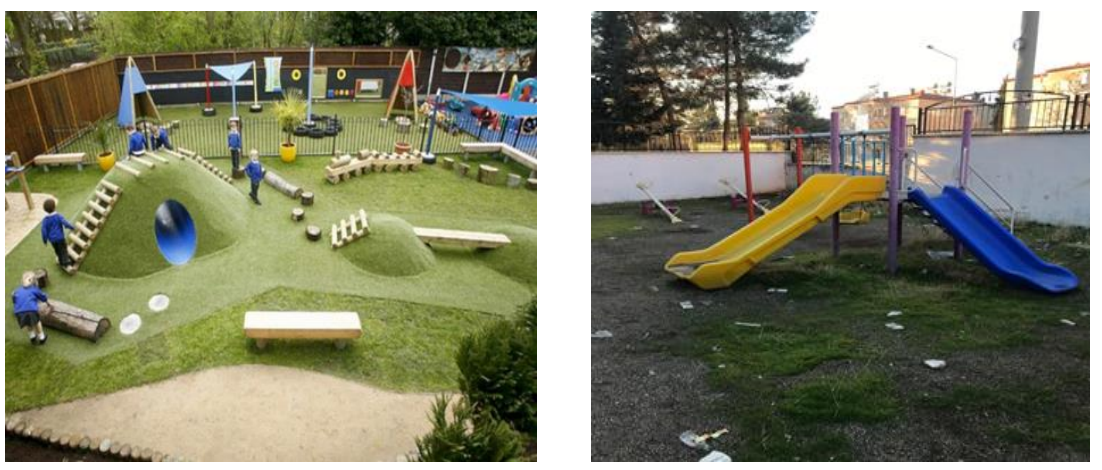

Sosyal alanlara yönelik fotoğraflar incelendiğinde, okul bahçelerinde grup oyunlarının oynanmasına yönelik alanların beton alanda oluşturuldukları görülmektedir. Ancak bu alanlar da tüm okullarda yer almamaktadır. Bununla birlikte sosyal alanı destekleyen drama alanı, oyun alanları, sosyalleşmeye yönelik grup alanları da gözlemlenmemiştir.

\section{Şekil 6.}

Sosyal oyun alanlarına yönelik örnek fotoğraf ve incelenen okul bahçelerine ait fotoğraf
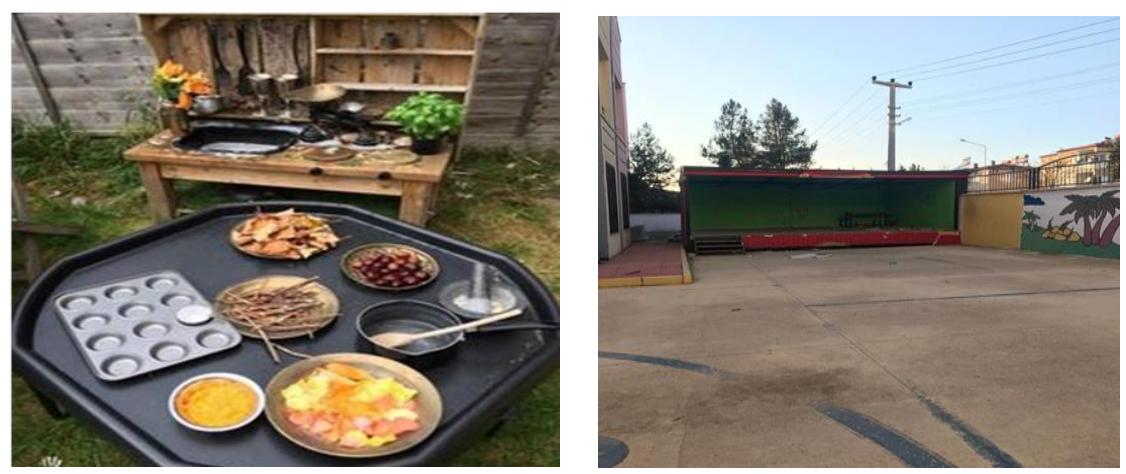

Duyu alanlarına yönelik fotoğraflar incelendiğinde okulların duyu alanına sahip olmadıkları görülmektedir. Bu nedenle duyu alanına yönelik fotoğraflar görülmemektedir. Duyulara yönelik oyunlar 
için okul bahçelerinde su ve kum havuzları bulundurulmalıdır. Belirtilen materyallerle etkileşime geçen çocuklar; pütürlü-kaygan, ıslak-kuru, sert-yumuşak, sıcak-ılık-soğuk gibi kavramları öğrenip pekiştirebilir ve bu bağlamda karşılaştırma, sınıflandırma gibi keşfetme ve bilimsel düşünme becerileri kazanabilmektedirler (Gansley, 2011).

\section{Şekil 7.}

Duyusal oyun alanlarına yönelik örnek fotoğraf

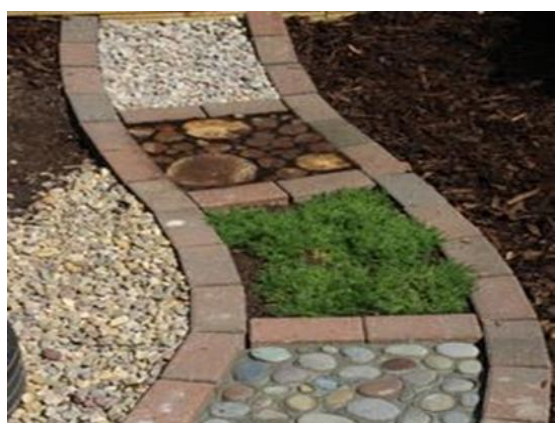

Yaratıcı alana yönelik fotoğraflar incelendiğinde, ağacın, oyun evinin vb. alanların birden çok amaç için kullanmaya elverişli oldukları gözlemlenmiştir. Ancak yaratıcı alanlar okulların çok azında bulunmaktadır.

\section{Şekil 8.}

Yaratııı oyun alanlarına yönelik örnek fotoğraf ve incelenen okul bahçelerine ait fotoğraf
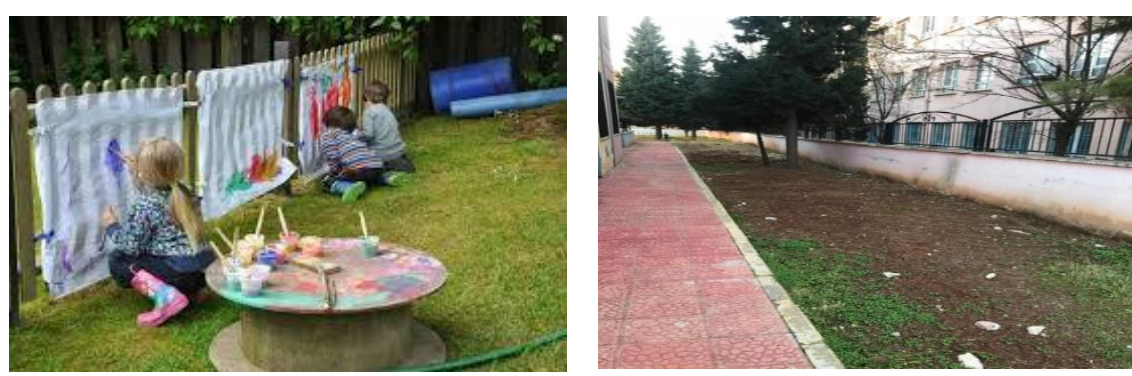

Sessiz alanlar incelendiğinde, okulların dinlenme banklarına veya dinlenmek için farklı alanlara sahip oldukları ancak bu alanların sınılı olduğu ve sesli alanlar ile iç içe oldukları görülmüştür.

\section{Şekil 9.}

\section{Sessiz oyun alanlarına yönelik örnek fotoğraf ve incelenen okul bahçelerine ait fotoğraf}
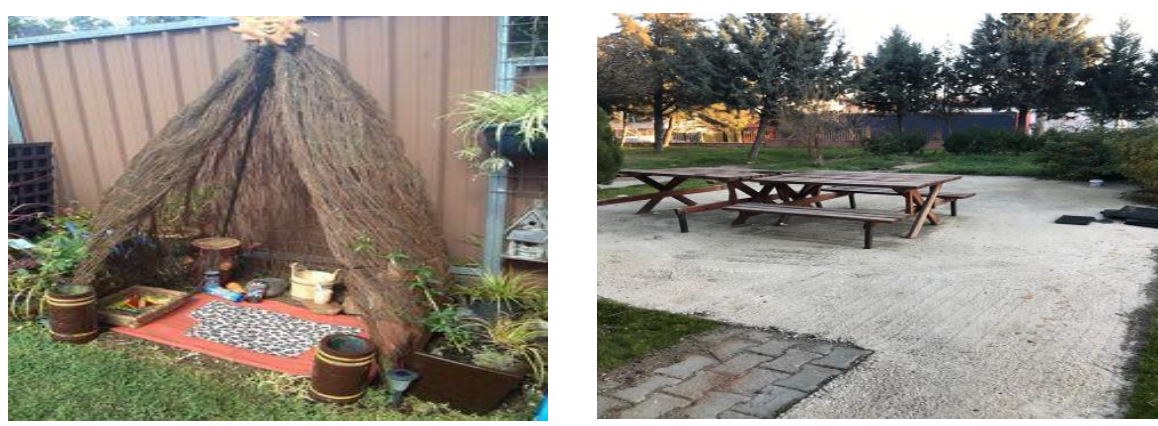

Okul bahçelerinin öğrenme ortamı olarak değerlendirilmesine ilişkin matris, kontrol listesi, renkli konum matrisleri ve fotoğraflar incelendiğinde, okulların en çok sahip olduğu alanların fiziksel alanlar ve 
sosyal alanlar oldukları ancak bu alanlarında amacına uygun olarak tasarlanmadıkları görülmektedir. Bu nedenle fiziksel alanların ve sosyal alanların güncellenmesi, duyu alanları, sessiz alanlar ve yaratıcı alanların da okullara kazandırıması gerekmektedir.

\section{Sonuçlar}

Okul bahçelerinin fiziksel bağlamda öğrenme ortamı olarak incelenmesini amaçlayan bu araştırmanın sonucunda:

- Okul bahçelerinin en fazla fiziksel alana sahip oldukları, sınırlı sayıda sosyal alanlara ve sessiz alanlara sahip oldukları, yaratıcı alanlara ve duyu alanlarına sahip olmadıkları görülmüştür.

- Var olan fiziksel alan ve sosyal alanın nicelik bakımından okul bahçelerinin tasarlanmasına elverişli oldukları ancak nitelik bakımından çeşitli materyaller ile zenginleştirilmesi gerektiği söylenebilir.

- Okullarda bulunan sessiz alanların genellikle dinlenme banklarından ibaret olduğu, çocukların sessiz ve özel bir alanda bulunmasına olanak sağlamadığı çünkü sesli alanlar ile iç içe tasarlandıkları söylenebilir.

- Yaratıcı alan ve duyu alanlarının okullarda neredeyse hiç yer bulmadıkları görülmüştür.

Araştırmanın sonuçlarının yola çıkılarak şu öneriler sunulabilir:

- Farklı şehir, farklı sosyoekonomik düzey ve farklı kurum türlerine göre okul bahçelerinin tasarlanması ve ya kullanılmasına yönelik daha fazla bilimsel çalışmanın yer alması

- Okul bahçelerinin öğrenme ortamı olarak düşünülmesi ve kullanılmasına yönelik hizmet içi eğitimler ile okul yöneticilerinin, öğretmenlerin ve personelin eğitilmesi

- Var olan okul bahçesi potansiyellerinin daha nitelikli kullanılması bağlamında Milli Eğitim Müdürlükleri, Üniversiteler ve Belediyelerin işbirliğinde projelerin hayata geçirilmesi

TR Dizin 2020 kuralları kapsamında çalışmalarda "Yükseköğretim Kurumları Bilimsel Araştırma ve Yayın Etiği Yönergesinde' yer alan tüm kurallara uyulmuş ve yönergenin ikinci bölümünde yer alan "Bilimsel Araştırma ve Yayın Etiğine Aykırı Eylemler" gerçekleştirilmemiştir.

\section{References}

21st Century School Fund. (2011). Developing great schoolyards: A handbook for elementary schools (1st ed.). Washington, DC: The Prince Charitable Trusts.

Aksu, Ö. V. ve Demirel, Ö. (2011). Trabzon kenti ilköğretim okul bahçelerinde tasarım ve alan kullanımları. SDÜ Orman Fakültesi Dergisi, 12(1), 40-46.

Aktaş Arnas, Y. (2019). Çocuk Merkezli Öğrenme Ortamları (2). Aktaş Arnas, Y. (Ed) Ankara: Pegem Akademi.

Aktaş Arnas, Y. ve İnceoğlu, S. (2019). Okul öncesi çocuklarda gelişim, öğrenme ve okul öncesi eğitim kurumlarında öğrenme ortamları. Aktaş Arnas, Y. (Ed) Ankara: Pegem Akademi.

Alat. Z. Akgümüş, Ö. ve Cavalı, D. (2012). Okul öncesi eğitimde açık hava etkinliklerine yönelik öğretmen tutum ve uygulamaları. Mersin Üniversitesi Eğitim Fakültesi Dergisi, 8(3), 47-62.

Arabacı, N. ve Çıtak, Ş. (2017). Okul Öncesi Dönemdeki Çocukların" Oyun" ve" Açık Alan (Bahçe)" Etkinlikleri İle İlgili Görüşlerinin İncelenmesi ve Örnek Bir Bahçe Düzenleme Çalışması. Akdeniz Eğitim Araştırmaları Dergisi, 11(21), 28-43. 
Aslan, F. (2010). Okul Öncesi Eğitim Kurumlarında Dış Mekan Tasarımında Çocukların Beklentilerinin Belirlenmesi. Ankara Üniversitesi Fen Bilimleri Enstitüsü Doktora Tezi.

Başar, M. A. (2020). Illkokul ve ortaokulların okul yeri durumları ve okul bahçesi olanakları. Journal of Orijinal Studies, 1(2), 61-84.

Başbay, A. M. (2012). Ankara ili sınırları çindeki özel ve resmi anasınıfı ve anaokulu bahçelerinin kullanım yönünden incelenmesi. Hacettepe Üniversitesi Eğitim Bilimleri Enstitüsü Yüksek Lisans Tezi.

Bilton, H. (2010). Outdoor learning in the early years: Management and innovation (3. Baskı). NY: Routledge.

Brett, A., Moore, R. C., \& Provenzo Jr, E. F. (1993). The complete playground book. Syracuse University Press.

Burdette, H. L., \& Whitaker, R. C. (2005). Resurrecting free play in young children: looking beyond fitness and fatness to attention, affiliation, and affect. Archives of pediatrics \& adolescent medicine, 159(1), 46-50.

Bundy, A.C. Luckett, T. Tranter, P.J. Naughton, G.A. Wyver, S.R. Ragen, J.ve Spies, G. (2009). "The Risk is that There is 'No Risk': A Simple, Innovative Intervention to Increase Children's Activity Levels", International Journal of Early Years Education, 17/1, 33-45.

Campbell, H. (2013). Landscape and child development. A design guide for early yers-kindergarten playlearning environments. Toronto: Toronto District School Board and Evergreen.

Cengiz, C. ve Ince, M. L. (2013). Farkıı okul ortamlarındaki çocukların okul sonrası fiziksel aktivitelerde algıladıkları öz-yeterlikleri. Yönetim Bilimleri Dergisi, 11(21), 135-147.

Cooper, A. (2015). Nature and the Outdoor Learning Environment: The Forgotten Resource in Early Childhood Education. International Journal of Early Childhood Environmental Education, 3(1), 85-97.

Copple, C. \& Bredekamp, S. (2009). Developmentally appropriate practice in early childhood programs serving children from birth through age 8 (Vol. 1313, pp. 22205-4101). Washington, DC: National Association for the Education of Young Children.

Çelik, A. (2012). Okul öncesi eğitim kurumlarında açık alan kullanımı: Kocaeli örneği. Atatürk Üniversitesi Ziraat Fakültesi Dergisi, 43(1), 79-88.

Çelik, A. ve Şahin, M. (2013). Spor ve çocuk gelişimi. The Journal of Academic Social Science Studies International Journal of Social Science, 6(1), 467-478.

Çukur, D. (2011). Erken Çocukluk Döneminde Görsel Algı Gelişimine Uygun 25 Mekân Tasarımı. Sosyal Politika Çalışmaları Dergisi, 24(24), 25-36.

Day, C. \& Midbjer, A. (2007). Environment and children. Passive lessons froö the everyday environment. Oxford: Architectural Press.

Dyment, J.E. Bell, A.C.\& Lucas, A.J. (2009). The relationship between school ground design and intensity of physical activity. Children's Geographies, 7(3), 261-276.

Del Alamo, M. R. (2005). Design for Fun: Playgrounds. Spain: LINKS International.

Gollwıtzer, G. V.D., (1959), Okul Bahçeleri, Çev. N. Taner ve P. Taner, Ankara.

Frost, J. L. Brown, P. S. Sutterby, J. A. \& Thornton, C. D. (2004). The developmental benefits of playgrounds. Childhood Education, 81(1), 42.

Huz, Ç, ve Kalburan, N. (2017). Eko-okul olan ve olmayan anaokullarının bahçe özellikleri ile öğretmenlerin bahçe özellikleri ve kullanımına ilişkin görüşleri. Elementary Education Online, 16(4).

Kaçan, M. O. Halmatov, M., ve Kartaltepe, O. (2017). Okul öncesi eğitim kurumları bahçelerinin incelenmesi. Erken Çocukluk Çalışmaları Dergisi, 1(1), 60-70.

Kalburan, N. C. (2014). Denizli ilinde bulunan resmi ve özel anaokulu bahçelerinin karşilaştirmali olarak incelenmesi. Pamukkale Üniversitesi Sosyal Bilimler Enstitüsü Dergisi, (18), 99-113. 
Karadağ, A. A. Mutlu, S. ve Sayın, Ş. (2012). Okul bahçelerinin oyun alanı olarak değeri: Düzce kenti örneği. Düzce Üniversitesi Ormancılık Dergisi, 8(2), 45-56.

Kıldan, A. O. (2007). Okul öncesi eğitim ortamları. Kastamonu Eğitim Dergisi, 15(2), 501-510.

Louv, R. (2005). Doğadaki Son Çocuk. Tübitak, Ankara

Malone, K. ve Tranter, P. (2003). “Children's Environmental Learning and the Use, Design and Management of Schoolgrounds", Children, Youth and Environments, 13(2).

MEB (2013). Milli Eğitim Bakanlığı Temel Eğitim Genel Müdürlüğü Okul Öncesi Eğitim Programı. https://tegm.meb.gov.tr/dosya/okuloncesi/ooproram.pdf adresine 13.01.2021de erişilmiştir.

MEB Mevzuat Bankası. (2004), Okul Öncesi Eğitim Kurumları Yönetmeliği. http://mevzuat.meb.gov.tr/html/25486-html adresinden alınmıştır.

Moore, R. C., \& Wong, H. H. (1997). Natural Learning: The Life of an Environmental Schoolyard. Creating Environments for Rediscovering Nature's Way of Teaching. MIG Communications.

Nur, i. (2019). Açık hava oyun/öğrenme ortamlarının tasarlanması ve düzenlenmesi. Çocuk Merkezli Öğrenme Ortamları (2). Aktaş Arnas, Y. (Ed) Ankara: Pegem Akademi.

Özdemir, A. (2011). Bir okul bahçesinin değişimi: Bartın Akpınar İlköğretim Okulu peyzaj projesi. İnönü Üniversitesi Sanat ve Tasarım Dergisi, 1(3).

Özdemir, A. ve Yılmaz, O. (2009). İlköğretim okulları bahçelerinin çocuk gelişimi ve sağlıklı yaşam üzerine etkilerinin incelenmesi. Milli Eğitim Dergisi, 181, 121-130.

Poyraz, H.ve Dere, H. (2003), Okul Öncesi Eğitimin Illke ve Yöntemleri, Ankara: Anı Yayıncılık.

Rivkin, M. S. (1995). The great outdoors: Restoring children's right to play outside. National Association for the Education of Young Children.

Tandoğan, O. (2016). Çocuklar İçin Daha Yaşanılır Okul Bahçeleri. Megaron, 11(4).

Tepebağ, D. ve Arnas, Y. A. (2017). Okul öncesi öğretmenlerinin okul bahçesini eğitsel amaçlı kullanımına yönelik görüşlerinin incelenmesi. Uluslararası Erken Çocukluk Eğitimi Çalışmaları Dergisi, 2(2), 50.

Uslu, A. \& Shakouri, N. (2012). Engelli çocuklara dost oyun alanı ve dış mekan tasarımı. Erciyes Üniversitesi Fen Bilimleri Enstitüsü Dergisi, 28(5), 367-374.

Uzut, N. (2020). Okul Öncesi Eğitim Kurumlarının İç Mimarlık Temelinde Mekân Ölçütleri: Diyanet İşleri Başkanlığı 4-6 Yaş Eğitim Merkezleri Örnekleri Üzerinden Bir Model Önerisi, Fatih Sultan Mehmet Vakıf Üniversitesi Lisansüstü Eğitim Enstitüsü İç Mimarlık Anabilim Dalı, Yayımlanmamış Yüksek Lisans Tezi

Vural, H., ve Yılmaz, S. (2016). İyileştirilmiş fiziksel çevre şartlarının ilkokul öğrencilerinin gelişimine etkisinin öğretmen gözüyle değerlendirilmesi. Bayburt Eğitim Fakültesi Dergisi, 11(2).

Vural, H., ve Yılmaz S. (2018). Erzurum Kenti Okul Bahçelerinin Fiziki Yeterlilikleri. Türk Tarım ve Doğa Bilimleri Dergisi, 5(2), 109-120.

Wake, S. J., \& Birdsall, S. (2016). Can school gardens deepen children's connection to nature. Space, place, and environment. Geographies of children and young people, 3, 89-113.

Wood L. \& Martin, K. (2010). What makes a good play area for children? Centre for the Built Environment and Health, The University of Western Australia. 